\title{
Chickpea responses to application of plant growth regulators, organics and nutrients
}

\begin{abstract}
The practice of agriculture is several thousand years old and faces many challenges worldwide. Among the pulse crops, the production of chickpea is one of most important thrust research area needs to be addressed seriously. Plethora of research investigations has been made to cover the various aspect of combined effect of plant growth regulators, organics and nutrients in the growth, physiological, biochemical, quality and yield characteristics of pulse crops which include length, fresh and dry weight of root, leaf number, leaf area, leaf area index (LAI), net assimilation rate (NAR), chlorophyll content, photosynthesis, nitrate reductase activity (NR), carbonic anhydrase activity (CA), nutrient accumulation, nitrogen, phosphorus and potassium contents, leg haemoglobin, protein and carbohydrate content and various other growth, yield and quality parameters. So the present review indicates that the process of growth and development, in addition to the yield and quality of plants is highly affected by the plant growth regulators, organics along with sulphur in stress and non-stressful circumstances critically to a greater extent.
\end{abstract}

Keywords: plant growth regulators, nutrients, yield, biological yield, quality characteristics
Volume 8 Issue 3 - 2018

\author{
Khalil Khan,' Mohammad Mazid² \\ 'Directorate of Research, Chandra Shekhar Azad University of \\ Agriculture and Technology, India \\ ${ }^{2}$ Faculty of Science, Invertis University, India
}

Correspondence: Khalil Khan, Directorate of Research,
Chandra Shekhar Azad University of Agriculture and Chandra Shekhar Azad Unive
Technology-208002, India.

Received: January 09, 2018 | Published: May 31 2018
Abbreviations: S, Sulphur; $\mathrm{SO}_{4}^{2-}$, Sulphate; PGR, Plant growth regulators; NAR, net assimilation rate; LAI, leaf area index

\section{Introduction}

The world food supplies are usually debated in terms of cereals, wheat, rice and maize being the dominant commodities, but there exists second group of crops, the pulse (legume grains), which make a major contribution to human diet (both in the peasant's hut and in the international hotels) in developing countries in tropical and subtropical areas, where their nutritional contribution is of paramount importance as a large segment of the populations in these areas have limited access to food of animal origin. ${ }^{1}$ In general, pulse crops are energy rich plants but are cultivated largely under energy starvation conditions and more than 92 per cent of the area under pulses is still under rainfed. The lower mean productivity of these crops is mainly due to cultivation in marginal lands and with little or no monetary inputs. Several attempts have been made to increase the yield potential of pulses, but they are primarily concerned with the use of fertilizers, pesticides and better management practices coupled with genetic improvement. On the pulse map of the world, India is largest producer, processor, consumers and importers of pulses with 25 percent share in global production (13.50 million tonnes). ${ }^{2}$ Pulses form an important part of Indian dietary, are essential adjuncts to a predominantly cereal-based diet and enhance the biological value of the protein consumed. The diverse agro-ecological conditions of the country are favourable for growing all the annual pulse crops including chickpea, pigeon pea, mungbean, urdbean, lentil and field pea, are important pulses crop contributing 39\%,21\%,10\%,7\% and $5 \%$ to the total production of pulses in the country. ${ }^{3}$ But, very little attention has been given to the physiological processes, which limit the crop productivity. Plant growth regulators (PGR's) are known to improve physiological efficiency including photosynthetic ability of plants and offer a significant role in realizing higher crop yields. The PGR's are also known to enhance the source-sink relationship and stimulate the translocation of photo-assimilates, thereby increasing the productivity. Though, the PGR's have great potential, its application and accrual assessment etc. have to be judiciously planned in terms of optimal concentration, stage of application, species specificity and seasons. In their wide spectrum of effectiveness on every aspect of plant growth, even a modest increase of 10-15 per cent could bring about an increment in the gross annual productivity by $10-15 \mathrm{~m}$ tons. Organic farming is a production system which largely excludes the use of synthetically compounded fertilizers, pesticides, growth regulators and livestock additives to the maximum extent. The basic reason that demands organic agriculture is the pollution of air, water and soil in varying degrees in different parts of the world which affects the environment and ultimately human welfare. Organic agriculture is a crop production method respecting the rules of nature. The objective is to achieve a sustainable farming system that preserves the environment and soil fertility for our offspring too. Though, traditional agriculture is a repository of several indigenous practices in respect of nutrition management and plant protection measures, there is a gradual erosion of these principles and practices due to over dependency on fertilizers and chemicals in recent years. ${ }^{4}$ Therefore, the promotion of organic farming through the use of organic materials and adopting ecologically sound plant protection measures would go a long way in bringing back the soil health. Among pulses, Chickpea (Cicer arietinum L.) is the most important pulse crop in the country grown in more than 6.93 million hectares area which contributes $62 \%$ of the global production (5.6 million tonnes) and about $37 \%$ of total pulse production in the India. ${ }^{5}$ These have played a key role in the agricultural economy of India from time immemorial. Also, chickpea is used in various ways. It is one of the earliest cultivated pulses, having been grown for over seven millennia, and currently account for almost $40 \%$ of total pulse production. Chickpea is very nutritive and is used as a protein adjunct to starchy diets. Seeds are widely consumed as pulse and in many other preparations. With its high nutritional value, chickpea is primarily a major source of protein, essential nutrients such as calcium, zinc and iron for the vegetarian populations. ${ }^{6}$ They 
are also eaten after roasting. Flour from the seeds is extensively used. It is also used in preparation of traditional weaning food 'Sattu' which is consumed by all age groups. Its seeds are largely fed to horses and leaves and staks are dried and used as fodder for cattle. Temph (an Indonesian fermented product) with high nutritional availability and meat like flavour is also prepared from chickpea. Flour from seeds is also used in textiles sizing and adhesives. Chickpea is officially included in the Indian pharmacopoeia. It is given as preventive diet to atherosclerosis patients because of its rich phosphorus content. It is an ingredient of a Unani-anti-hypersensitive drug 'Ajmaloon'. Whole germinated seeds are used as a prophylactic against deficiency diseases, scurvy in particular in famine affected areas. Because seeds has saccharine, glucose, fructose, polysaccharides including starch, $\gamma$-galactan, levulose, P-galacto-araban, betaine, choline adenine, saponins, phytin, citric acid and malic acid etc. A preparation of $25 \%$ chickpea meal and $75 \%$ groundnut meal used as a corrective in malnourished people and as a cure for Kwaserkhor and other protein deficiency diseases.

Immature pods and fresh sporulated gram has phospho-enolpyruvate carboxylase and has a biochanin- $\mathrm{A}, \mathrm{B}$ and $\mathrm{C}$ and also is a cheap and easily available source of vitamins-C (ascorbic acid) used to accelerating the growth of the yeast cells and in prevention of scurvy in famine affected areas. The seeds of gram have anti-nutritional factors which can be reduced or destroyed by heating fermentation or germination of seeds. According to an estimate for the year 2008-2009, the total production of pulse in India is 14.18 million tonnes, which is $3.9 \%$ lower than the production in 2007-08 and 8.5\% lower than the targeted production for 2008-09. The gap was filled by imports. ${ }^{7}$ In addition, the world's total production of chickpea covers around 8.5 million metric tonnes annually and is grown over 10 million hectares of land approximately. In Indian context, the average annual area and production of chickpea are about 7-8 million hectares and about 4-5 million tonnes of grain respectively. In India, the low productivity of chickpea is due to several factors. ${ }^{8} \mathrm{~A}$ few of these are described here;

a) More than $75 \%$ of Indian farmers has own small or marginal holdings of less than two hectares,

b) severe drought in several parts of India during 2001 to 2003 led to sudden decline in chickpea area during that triennium. ${ }^{9}$

c) The production of chickpea is also affected in excessive cold conditions,

d) It is mainly grown as a cool-season crop under both rain fed (79\%) and irrigated condition and often maturing in the driest and hottest part of the year,

e) Most farmers are ignorant of the techniques of cultivation of high yielding varieties, post-harvest technology and proper processing facilities,

f) About one third of flowers produced do not develop in to fruits,

g) Pests and diseases reduce the yields further as chickpea pods are mere prone to these,

h) Sudden excessive rain soon after sowing or at flowering does great harm,

i) An early hot summer shortens the growing period, hastens maturity and reduces yield,

j) Hailstorms at ripening cause much damage, k) Lack of knowledge of precise dose of fertilizers recommended by the Agriculture Department for a particular cultivar and region..$^{10}$ and

1) Low or no use of fertilizers due to scarcity of funds; ; ${ }^{11,12}$ Further, it has been established that species of a genes (and even varieties of a species) differ, in their ability to fully utilize in puts, including nutrients, under the same environmental conditions. ${ }^{13}$

India is the principal chickpea producing country ( $83 \%$ share in the region). The chickpea area marginally declined from $9.3 \mathrm{~m}$ ha to $9.0 \mathrm{~m}$ ha during the triennium 1975-77 to 2004-2006. However, production slightly increased from 6.0 to 6.7 million tonnes and productivity from 642 to $733 \mathrm{~kg} \mathrm{ha}^{-1}$ during this period. Therefore, to meet the challenges of low chickpea production and local requirements, there is need to adopt a multipronged strategy which involves enhancing chickpea production through adaptation of improved technology. ${ }^{3}$ To achieve this goal, the Indian council of Agricultural Research (ICAR) has established several research centres in different parts of the country to deal with various pulse crops, including two for chickpea improvement are the International Centre for Agricultural Research in the Dry Areas (ICARDA) and the International Crops Research Institute for the Semi-arid Tropics (ICRISAT). Also, many research projects and national programs have been launched by nongovernment organizations to boost the production of chickpea and the technology is being increasingly adopted by farmers. Commercial cultivation of chickpea for both protein-rich supplement to cereal based diets, especially critical in developing countries where people either cannot afford animal protein or are vegetarian by choice ${ }^{14,15}$ and in sustaining soil fertility by fixing up to $140 \mathrm{~kg} \mathrm{~N} \mathrm{ha}^{-1}$ year $^{-1}$ (organic cropping systems). ${ }^{16}$ Thus, chickpea is clearly not cost effective and attempts have been made to produce a dual purpose chickpea crop with good yield and more $\mathrm{N}_{2}$-fixation. However, little progress has been made in breeding dual purpose varieties synchronized for both seed yield and organic cropping. Under these circumstances, the best strategy for dual-purpose chickpea would be to increase the height (root + shoot length) or number of root nodules on root systems of the plant and to improve seed weight, a task which may prove simpler than achieving the synchronizing of seed organic cropping.

Also, increasing use of high analysis fertilizers results in a growing deficiency of secondary nutrients and micro-nutrients. Further, much of the fertilizers are rendered unavailable to the plants if applied as a single dose at sowing due to many factors. Seed filling is a critical stage for pulse crops. Seed yield and quality of storage protein are influenced by both $\mathrm{S}$ and nitrogen nutrition during seed filling. Since pulse crops have the ability to fix nitrogen for the atmosphere, their nitrogen requirement from the soil is lower than that of other crops. However, studies have shown that nitrogen stress can result in decrease in seed yield and protein concentration. ${ }^{17,18}$ For example, up to $60 \%$ of total applied S may be lost through leaching and volatilization etc, ${ }^{19}$ and up to $70 \%$ of the phosphorous (P) by fixation..$^{20,21}$ Thus, for achieving the desired productivity, the limiting nutrients need to be supplied judiciously using innovative methods of application. As mentioned earlier, a majority of farmers (75\%) has marginal holdings of less than two hectares. Therefore, with such a limitation on increasing the acreage for cultivation, it is highly desirable to innovate ways which can augment the yields. ${ }^{1}$ In most region of the world, chickpea is primarily used as human food. In all regions except North and Central America, $70-80 \%$ of the domestic supplies of chickpea is established, and the yields and production costs are improved, it 
is likely to remain a subsistent crop in developing nation. Hence, attention should be focused on improving chickpea yield and seed quality, and increasing resistance to factors, which reduce yield such as low temperature disease, insects and pests. This will help raise the productivity and profitability of chickpea, particularly in the India, largest chickpea producing country, where yields are low;22-24 Another measure to improve the importance and the value of chickpea would be the expression of the area under chickpea in several countries of United States America and where the present area is very small but yields are higher than in the traditional chickpea producing countries, especially India and Pakistan.

The high yield of chickpea through input use in European countries is yet another approach to increase world chickpea production. ${ }^{25}$ Finally, because of some recent improvements in chickpea market price, and the relative low costs of productions, chickpea has improved its position in rain fed or partially irrigated areas. This trend needs to be consolidated through the development and large-scale adaptation of high yielding varieties, which are resistant to biotic and abiotic factors that currently impair production. ${ }^{26}$ This may add further to the profitability of chickpea and go a long way towards changing status of chickpea from a subsistence crop to an internationally traded commercial crop. ${ }^{27}$ One such approach the could be to make plants utilize fully the available resources leading to maximum harvesting of solar energy and subsequently increasing the number of active sinks. To achieve this, plant growth regulators (PGRs) could be used as they are known to affect many facets of plant life including growth, flowering, fruiting and ion transport ${ }^{10,28-31}$ In spite of PGRs, also, separately or synergistically the application of macro-nutrient viz., $\mathrm{S}$ might prove helpful in providing mechanical support and improve nodulation activity ${ }^{4,32-33}$ to the plants by strengthening the middle lamellae of stem cells and improving $\mathrm{S}$ content of nitrogenase. ${ }^{34}$ and of ferredoxin. ${ }^{35}$

\section{Plant growth regulators}

The PGRs are organic natural or synthetic compounds (other than nutrients). They are naturally produced within plants, though very similar chemicals are produced by fungi and bacteria that can also affect plant growth as well as human use them to control plant growth and development. ${ }^{36}$ On other hand, PGRs are chemicals produced by plant that alter growth pattern and/or maintenance of the plant. They can be found in many cells and tissues, although they seem to be concentrated in meristem and buds. They control cell activation by sending chemical signals or messenger to cells to do something or to not do something including activating the genes that code for specific enzymes. They inhibit as well as promote cellular activities. Most PGRs have multiple effects in plants and they work in very small concentrations. PGRs often work in conjunction with each other and have overlapping effects. There are several classes of PGRs, viz., gibberellins, auxins, cytokinins, abscissic acid and ethylene. Additionally, a number of recently "discovered" PGRs remotely related with the above PGRs has varied important roles in the regulation of plant activities. These include Brassinosteroids, salicylates, jasmonates and triacontanol. Interestingly, the synthetic growth regulators bring about the more or less same plant responses when applied exogenously at very low concentrations. So the agrophysiologists are moving in a direction where the physiological efficiency of the plant including the photosynthetic rate and nitrogen fixation, water and mineral uptake, leaf senescence, better harvest index and stress resistance may be improved by using PGRs.
Auxins enhance a number of physiological processes in plants, including abscission of older mature leaves and fruits, apical dominance, cell division, cell-enlargement, distribution of growth between primary and lateral root and shoot meristem, flowering and parthenocarpy, loosening of cell-wall, mediation of terroristic responses of shoot and roots to light and gravity, patterning of embryos, root initiation, synthesis of ribonucleic acid (RNA), deoxyribonucleic acid (DNA) and protein and vascular tissue differentiation. ${ }^{37,38}$ Cytokinins enhance a number of physiological processes in plants, including activation of cell growth in leaves, apical-dominance, breaking of bud dormancy, cell-cycling, chloroplast differentiation, floraldevelopment, leaf-senescence, nutrient mobilization, N-dependent regulation of gene expression in photosynthesis, $P_{\mathrm{N}}$, seed germination and source-sink balance..$^{39,40}$ In addition, gibberellins inhibit the adventitious root formation but enhance a number of physiological processes including activity of ribulose-1,5-bisphosphate carboxylase (Ru BP case), bunching of grapes, breaking of seed and bud dormancy, cell-wall plasticity, cell elongation, flowering, growth and yield of sugarcane, $P_{\mathrm{N}}$, parthenocarpic, protein-synthesis, phloem-loading, relative growth rate (RGR), Stomatal aperture, senescence, stemelongation, seed-germination, synthesis and secretion of hydrolyzing enzymes particularly $\alpha$-amylase for promoting hydrolysis of storage-reserves, transpiration rate, transcription of messenger (m)RNA and vernalization. ${ }^{14,42}$ SA reduces ethylene biosynthesis and enhances a number of physiological processes, including defence mechanism against abiotic and biotic stress, membrane permeability, photosynthesis, seed germination, specific changes in leaf anatomy and chloroplast structure, synthesis of auxin and cytokinins and transpiration rate (El-Tayeb, 2005).

PGRs significantly influence agronomical, morphological and physiological traits in crops and it was observed that at limited concentration they stimulate rapid cell division resulting faster vegetative and reproductive growth. ${ }^{43}$ They supplies either carbon and energy or essential mineral elements and active in very small quantity (e.g., $<1 \mathrm{mM}$, often $1 \mu \mathrm{M}$ ) which found in certain parts of the plant and usually translocated to other sites, where they evokes specific biochemical, physiological and or morphological responses; ${ }^{44-46}$ Moreover, PGRs are important agents in the response of plants to the external physiological environment. ${ }^{47}$ The increase in yield with the application of various PGRs might be due to increased yield attributes, which in turn resulted from effective translocation of photosynthesis. The plant growth regulators also increases mobilization of reserve food materials to the developing sink through increase in hydrolyzing and oxidizing enzyme activities and leads to increase in yield ${ }^{48,49}$ observed that exogenously supplied PGRs may undergo several metabolic processes in the soil resulting in loss of their activity and reduced availability to plants and such type of behaviour was only seen with auxin (e.g., IAA) and $\mathrm{GA}_{3},{ }^{50-60}$ In addition, remarkable accomplishments of PGRs such as manipulating plant developments, enhancing yield and quality have been actualized in recent years using new emerging and efficient PGRs. It has long been ascertained that plant hormones (e.g., auxin, cytokinins gibberellins and ethylene) are involved in controlling developmental events such as cell division, cell elongation and protein synthesis. Plants have the ability to store excessive amounts of exogenously supplied hormones in the form of reversible conjugates which release active hormone when and where plant needs them during the growth period. PGR are proved to improve effective partitioning and translocation of accumulates from source to sink in the field crops; $;$ 61,62 


\section{Inorganic plant mineral nutrition}

Low availability of plant nutrients limits yield in many crops. ${ }^{63}$ Inorganic ions obtained from the soil having specific and essential functions in plants are called mineral nutrients and their absorption, translocation and metabolism refer to as mineral nutrition. The contribution of plant nutrition as a science bloomed in the $20^{\text {th }}$ century. In due course of time, the essentiality of using seven other elements, viz., boran $(\mathrm{B})$, chlorine $(\mathrm{Cl})$, copper $(\mathrm{Cu})$, manganese $(\mathrm{Mn})$, molybdenum (Mo), nickel (Ni) and zinc ( $\mathrm{Zn})$, has been established on the basis of sophisticated analytical techniques to purify salts and the water for hydrophonic cultures, ${ }^{44,64,65}$ Among these, $\mathrm{S}$ represents the $9^{\text {th }}$ and least abundant essential macro-elements in plants, preceded by $\mathrm{C}, \mathrm{O}, \mathrm{H}, \mathrm{N}, \mathrm{K}, \mathrm{Ca}, \mathrm{Mg}$, and $\mathrm{P}$. The dry matter of $\mathrm{S}$ in plants is only about $1 / 15$ of that of N. Moreover, S plays critical roles in the catalytic or electrochemical fractions of the bio molecules in cells and also as signalling molecules for fundamental cellular functions ${ }^{66,67} \mathrm{~S}$ is one of the essential nutrients and it contributes to yield and quality of crops. $\mathrm{S}$ occurs in a wide variety of organic and inorganic combinations. $\mathrm{S}$ is present in nature in both inorganic and organic forms. $\mathrm{S}$ is cycled in ecosystem in nature where conversion of sulphate to organic $S$ compounds is primarily dependent on sulphate uptake and reduction pathways in photosynthetic organisms and microorganisms. The transfer of $\mathrm{S}$ between the organic and inorganic pools is entirely caused by the activity of the soil biota, particularly the soil microbial biomass, which has the greatest potential for both mineralization and also for subsequent transformation of the oxidation state of S. S oxidation is the most important step of S cycle, which improves soil fertility. It results in the formation of sulphate, which can be used by the plants, while the acidity produced by oxidation helps to solubilise plant nutrients and improves alkali soils. ${ }^{68}$ In addition, $\mathrm{S}$ is required at 0.1 to 1.0 (on a dry weight basis) for growth and development. $\mathrm{S}$ is mainly taken up by lands via the roots from the soil and translocated simplistically through endodermal cells to the stele for distribution to the various plant tissues; ${ }^{69,70}$ Plant canopies are a strong sink for deposition of atmospheric sulphur dioxide, which enters mainly through the Stomatal apertures. ${ }^{71-73}$

On other hand, $\mathrm{S}$ is a part of every living cell and is a constituent of two of the 21 amino acids which form proteins. The benefits from $\mathrm{S}$ fertilization of crops can be traced to its role in protein development, to improvement of $\mathrm{N}$ use, etc. However, in recent years, $\mathrm{S}$ deficiency has become an increasing problem for agriculture resulting in decreased crops quality parameters and yield. ${ }^{74,75}$ Although, the availability of S needed for profitable crop production continues to decline. Reasons for the decline include the emphasis on improved air quality, the increasing amount of $\mathrm{S}$ removed from the soil by higher yielding crops and use of modern fertilizers containing less S. Up to $90 \%$ of the total $\mathrm{S}$ is present in most plants as cysteine and methionine that, in turn, are predominantly bound in protein. ${ }^{76}$ Because methionine is one of the ten amino acids essential for animal nutrition, there has been sustained interest increasing the concentration of methionine in plant material used for feed and food. Most reported attempts to increase seed $\mathrm{S}$ amino acid concentration by adding S-rich sink protein have methionine with success, but some of these modified seeds have been reported to display alterations in endogenous protein composition similar to those triggered by $\mathrm{S}$ nutritional deficiency. Reduced $\mathrm{S}$ is required in the function of cofactors, such as acetyl co-enzyme A, thiamine, biotin and lipoic acid. The S containing tri peptide glutathione is involved in the regulation of protein synthesis, ${ }^{77}$ and in the compensation of various forms of stress. Both functions of glutathione are highly significant for the survival of plants in a stressful environment. Moreover, S containing plant secondary compounds, like allicin and isothiocyanate derivatives can be important for phytomedical applications. There are many S-containing compounds, which have been limited, directly or indirectly, with the defence of plants against microbial pathogens; these include thionins, defensins glucosinolates, crucifer phytoalexins, alliin and glutathione. ${ }^{78}$

Appropriate applications of fertilizers can remedy deficiencies in many instances; however, they remain considerable uncertainties regarding timing and type of S-application which, in turn, influence the persistence of the $\mathrm{S}$ in the soil and the availability to the plant. A common situation is one in which there are a substantial seasonal variation in $\mathrm{S}$ available to the plant and ideally, crops will be engineered to maximize uptake when $S$ is abundant and therefore be better able to tolerate periods of low-S availability. Modern agriculture requires adequate fertilization of $S$ to achieve maximum crop yield and performances. Plants use sulphate, the oxidized form of S existing in the soil, as an $\mathrm{S}$ source. ${ }^{79-81}$ By contrast, animals including humans require S-containing amino acids and proteins as dietary $\mathrm{S}$ sources because of their inability to assimilate sulphate into Cys and Met. Significance of plant sulphate assimilatory pathway is manifested by its ability to fill this metabolic gap in the global $\mathrm{S}$ cycle in nature. ${ }^{79} \mathrm{In}$ addition to its basic nutritional importance, $\mathrm{S}$ is present in numbers of plant metabolites representing important biological activities as redox controller, vitamins, co-enzymes, flavones and defence chemicals and other secondary metabolites. ${ }^{79,80-83} \mathrm{~S}$ is probably the best-described nutrient with respect to correlated behaviour of metabolites and transcripts during the deficiency responses. $\mathrm{S}$ is necessary for proper growth and development of living organisms; however, it is attributed rather catalytic and regulatory than structural functions because it is much less abundant than other macro elements. The plant biomass as consumed as food and feed serves as the main sources of organic $\mathrm{S}$ for animals and humans. ${ }^{84,85}$

\section{Interaction effect on growth and yield characteristics}

Leaf area and other growth parameters were influenced by different growth regulators in pulse crops ${ }^{86-88}$ The PGRs had greater influence on plants which showed comparable values of LAI (Leaf area index), LAD (Leaf area dry matter), CGR (Crop growth rate), NAR (Nitrate assimilation rate) and TDM over control plants. LAI, CGR, NAR and AGDM (Average ground dry matter) had a significant linear relationship with seed yield. Kumar et al., ${ }^{89}$ studied the effect of $\mathrm{S}$ and PGRs on yield and quality parameters of chickpea and reported improved grain, straw yield, and protein content. The application of PGRs to pollinated buds once and twice daily increased bud retention many folds. ${ }^{90}$ Percent bud retention was significantly higher when the growth regulators were applied twice. Moreover, triacontanol singly or with potassium nitrate enhances pod setting, 100-seed weight, biomass, harvest index and seed yield at harvest as well as reduces flower abortion in chickpea. ${ }^{91,92}$ Reported that all the yield contributing parameters including flower retention, pod setting percentage, pod number and seed weight, increased by application of $\mathrm{GA}_{3}$ and cycocel treatments. Foliar application of GA $(10 \mathrm{ppm}), \mathrm{NAA}(20 \mathrm{ppm})$ cycocel $(25 \mathrm{ppm})$ recorded the significant increase in the plant height, number of primary and secondary branches per plant, chlorophyll $a$ and $b$, total chlorophyll content, seed protein content, number of pods per plant, seed per plant, 100-grain weight, grain yield per plant per hectare and harvest index. Increase in number of flowers per plant, 
percentage of pod set per plant, number of pods per plant, number of seed per plant pods, 100 seed weight, seed-yield and productivity of chickpea cv. Avrodhi was reported by application of TIBA, AlAR triacontanol, IAA, cytokinin and NAA. ${ }^{3}$ The combined application of $50 \mathrm{~kg} \mathrm{P} \mathrm{P}_{5}$ plus $20 \mathrm{~kg} /$ ha with FYM and PGR particularly triacontanol raised grain productivity grain protein, protein yield. ${ }^{94}$

Moreover, kinetin was found to be most effective in increasing growth parameters (viz., root/shoot biomass, growth yield) and N-fixation (viz., specific nitrogenase activity of nodules, and total $\mathrm{N}$-fixed per plant) of chickpea. The kinetin seed soaking with (10$5 \mathrm{M})$ and $\mathrm{ABA}$ foliar spray (10-6M) were more effective in increasing the grain weight as compared to control. The foliar application of PGRs increased the seed yield components i.e., number of seed per plant, number of pods per plant, and 100- grain weight. Besides this, Tripathi et al. ${ }^{95}$ studied the effect of PGRs on chick pea cv. Avorodhi and reported that dry matter production, protein and starch content were highest with the 20ppm TIBA, 5pppm cytokinin and 50ppm IAA treated respectively. Moreover, Raut \& Sabale ${ }^{96}$ studied the effect of fertilizers and PGRs under irrigated conditions and revealed that they increased plant height, branch number, dry matter, grain weight per plant, harvest index and grain and stover yields increased the with increasing fertilizer rate. In this trend, other PGRs (CCC, paclobutrazol) and anti transparent (calcium carbonate, kaolin and china clay) were found to be effective to enhancing the growth of chickpea cv. Phule G-5 when this sprayed during the flowering and days after the initial flowering and among PGRs CCC gave the highest number of pods per plant and grain yields and were either as effective as or less effective than the control plants. ${ }^{97}$ Namdeo et al., ${ }^{98}$ first reported that foliar application of $250 \mathrm{ml}$ triacontanol produced the highest growth and yield components with an increase in grain yield compared to the control plants of chickpea cv. Secondly, foliar spray of $0.5 \mathrm{mg} \mathrm{dm}^{-3}$ TRIA significantly promoted the plant height, fresh mass and also stimulated the onset of flowering, pod production and retention, but less number of pods and seeds per plant. ${ }^{99}$

As next evidence, Fatima et al., ${ }^{100}$ compare the effect of three PGRs (kinetin, IAA and ABA) at single or integrated form on growth and yield parameters and N-fixation of Chickpea under natural conditions and reported that kinetin found to be most effective in increasing growth parameters (viz., root/shoot length biomass, grain yield) and $\mathrm{N}$-fixation (viz., specific nitrogenase activity of nodules and total N-fixed per plant. Moreover, ABA significantly decreased nodule weight, nitrogenase activity of nodule, specific nitrogenase activity of nodules and total N-fixed per plant. LA, LAI, CGR, NAR and AGDM accumulation found to be enhanced with application of PGRs (potassium naphthenate (Knap) and naphthalene acetate acid (NAA) as foliar spray. ${ }^{31}$ The application of $\mathrm{GA}_{3}$ at vegetative stage of chickpea cv. $\mathrm{C} 727$ showed more reduction than at flower initiation stage while length and fresh weight of root remained unaffected ${ }^{101,102}$ The cumulative effects of PGRs included reduction of soil salinity and improvement of soil fertility and increase in chickpea cv. Chaffa yield. Meena et al., ${ }^{103}$ applied $40 \mathrm{~kg} \mathrm{~S} / \mathrm{ha}$ and $5 \mathrm{~kg} \mathrm{Zn} / \mathrm{ha}$ and reported the significant increase in growth, yield, protein content, nutrient content and nutrient uptake. Patil et al., ${ }^{104}$ studied the effect of organic manures and rock phosphate on growth and yield of chickpea and significantly higher grain yield was recorded with rock phosphate application of $200 \mathrm{~kg} / \mathrm{ha}(2140 \mathrm{~kg} / \mathrm{ha})$ over $50 \mathrm{~kg}$ and $1000 \mathrm{~kg}$ of rock phosphate/ha except rock phosphate $150 \mathrm{~kg} / \mathrm{ha}(2069 \mathrm{~kg} / \mathrm{ha})$. Increase in $\mathrm{N}$ uptake due to $\mathrm{S}$ application has been reported by Scherer et al., ${ }^{105}$ and Tiwari \& Gupta. ${ }^{43} \mathrm{~S}$ can readily alter primary and lateral root growth, modifying the overall root architecture. ${ }^{102}$ Increased $\mathrm{N}$ uptake may also be argued that increased $\mathrm{S}$ availability resulted in better root and shoot growth and ultimately increased $\mathrm{N}$ uptake due to increased dry matter production. Application of 50ppm mepiquat chloride, $1.25 \mathrm{ppm}$ triacontanol, $0.2 \%$ borax and $1 \%$ potassium nitrate resulted in the height flowers setting, 100-seed weight, biomass at harvest, seed yield and harvest index and lowest number of aborted flowers. ${ }^{91}$ Furthermore, GA treatment was useful to increase shoot length, mobilization efficiency, emergence index, speed of germination and co-efficiency of germination while oxygenated peptone showed an upper hand in root length, shoot/root ratio, biomass and vigour index. ${ }^{106}$ Application of $\mathrm{S}$ with or without $\mathrm{P}$ recorded significantly higher seed yield showed significantly higher seed yield than saline in chickpea cv. BG-209 on application of P and S (0,40 and 80kg/ha) and $\mathrm{P}\left(40 \mathrm{~kg} \mathrm{~S}+40 \mathrm{~kg} \mathrm{P}_{2} \mathrm{O}_{5}\right.$ and $\left.80 \mathrm{~kg} \mathrm{~S}+40 \mathrm{~kg} \mathrm{P}_{2} \mathrm{O}_{5} / \mathrm{ha}\right) .{ }^{107,108}$ reported that $40 \mathrm{~kg} \mathrm{~S} /$ ha resulted in better growth, yield attributes, consumptive use, water use efficiency and $\mathrm{S}$ uptake than no $\mathrm{S}$ and $20 \mathrm{~kg} \mathrm{~S} / \mathrm{ha}$.

\section{Synergistic effect of PGRs and sulphur on physiological characteristics}

(a) Chlorophyll: Chlorophyll content of plants was observed to be invariably influenced with the application of growth substances and supplementation of minerals. Tripathi et al., ${ }^{95}$ reported that chlorophyll content was highest in chickpea cv. Avoradhi, with 20ppm TIBA treatment at present and past-anthesis respectively among the treatment including ALAR (dominozide), Miraculam, GA, NAO and Plaofix, cytokinins, triacontanol and CCC (chlormequat). The chlorophyll content of the leaf is influenced by optimum dose of $\mathrm{S}$ nutrition and it significantly increased in case of soyabean leaves. ${ }^{109}$ but at higher rate applied S did not further increase the chlorophyll content of leaves and significantly reduced. Chlorosis is a common symptom of S deficiency in plant species. ${ }^{110}$ Circumstantial evidences indicate that S-deficiency greatly diminishes carbon-fixation of Medicago sativa, which is assumed to be caused by the reduction in the synthesis of key carbon metabolic enzymes as a result of reduction in the pods of the free S-containing amino acids. The Chl content is reduced because of a general reduction of PSII and PSI and the associated light-harvesting antenna. The Rubisco content is also significantly reduced in the S-deprived plants. The imbalances between PSII and PSI, and between photosynthesis and carbon fixation led to a general over-reduction of the photosynthetic electron carriers. Moreover, chromatographic analysis showed that the level of monosaccharides is lower and starch content higher in the S-deprived plants. ${ }^{111}$ While no change in metabolite levels are found in the TCA or Calvin cycle. ${ }^{111}$ Hajouj et al. ${ }^{112}$ reported the Ck delay the initiation of leaf senescence and bring about the promotion of photosynthetic activity mainly by increasing the chlorophyll content. ${ }^{110}$ Moreover, Chaloupkova \& Smart ${ }^{113}$ reported the application of ABA significantly decreased chlorophyll content. ABA application enhances senescence more in old leaves as reported by ${ }^{114}$ whereas young leaves were less affected by ABA. ABA is synthesized from xanthophylls intermediate. The initial steps of ABA biosynthesis take place in chloroplasts and other plastids. ${ }^{41}$ Moreover, result of Karim \& Fattah ${ }^{31}$ indicated that $1500 \mathrm{ppm}$ potassium naphthenate spray on chickpea plants at first flowering stage (45days) could be positively effective for growth and development of plants with higher values of physiological characteristics.

(b) Photosynthesis: Under the condition of effect of S limitation, the pulse crops showed reduced growth and photosynthetic rates. ${ }^{115}$ 
$\mathrm{S}^{2-}$ a major form of sulphate in aqueous phase of apoplast, may reduce photosynthetic rate and thereby crop yield through inducing ROS, involved in $\mathrm{S}^{2-}$-induced stress. ${ }^{116} \mathrm{~A}$ decrease in the yield of some crops due to decreased atmospheric $\mathrm{S}$ input has been reported for northern Europe. ${ }^{117}$ Kapila and Singh, 2009). General responses to S limitation are reduced growth and photosynthesis, ${ }^{118}$ and strong reduction in photosynthesis under S-limited growth correlates with a substantial decline of Rubisco and chlorophyll $\mathrm{a} / \mathrm{b}$ binding protein. ${ }^{119,120}$ According to Sexton et al., ${ }^{121} \mathrm{~S}$ deficiency at first influences the protein synthesis and later on photosynthesis. The photosynthetic apparatus is severely affected under S deficiency. However, as with $\mathrm{N}$ deficiency under $\mathrm{S}$ deficiency, shoot growth is more depressed than root growth. Moreover, a strong inhibition of shoot growth but continuation of root growth under nutrient deficiency might mainly reflect alteration in photosynthetic allocation. ${ }^{122}$ Grewal et al., ${ }^{123}$ observed indirect evidence of improved photosynthetic activities in chickpea by enhancing chlorophyll content and retaining higher LAI with $\mathrm{N}(50$ and $100 \mathrm{~kg} / \mathrm{ha})$, spray of CCC (250 and 500ppm) and Ethrel (500ppm). The kinetin application maximizes the shoot/root weight which could be attributed to $\mathrm{Ck}$ regulation of photosynthetic capacity due to kinetin treatment is related with increase in total biomass due to kinetin treatment is related with increase in photosynthetic activity. Cares and Vendrig ${ }^{124}$ reported that application of Cks promote photosynthetic activity mainly by means of increase in leaf chlorophyll content. Hardy \& Havelk ${ }^{125}$ and Bethlenfalvay \& Phillips ${ }^{126}$ reported the pivotal role of photosynthesis in $\mathrm{N}$-fixation.

(c) Protein content: It is assumed that yield depression under S deficiency conditions is the result of a limiting protein synthesis. Protein content of chickpea seeds were observed to be invariably influenced with the application of growth substances and supplementation of nutrients. Gupta et al., ${ }^{90}$ reported the favourable effect of PGRs on the protein content in Chickpea also. Kumar et al., ${ }^{87}$ suggests the cumulative effects of PGRs plus S on increasing content of protein in chickpea also as reported by Yadav \& Bharud ${ }^{127}$ through combined foliar application of $\mathrm{GA}_{3}$, NAA and cycoel, benzyladenine, biforce and biopower. In addition, foliar applications of SA and brassinolide also have enhancing effect on protein content of chickpea seeds cv. GG1. ${ }^{128}$ Increase in protein and sugars content of leaves related with the increase in nodule activity at the flowering and early pod filling stages, thereafter, degradation of chlorophyll and protein content become more pronoununced in old leaves as compared to young leaves. ${ }^{10}$ Single super phosphate, gypsum and elemental S provide $\mathrm{S}$ nutrition during seed development in Chickpea cultivars (PBG1 and BG 1053), and Jyoti et al., ${ }^{129}$ also reported the significant increase in the biomass content, seed-S containing amino acids as well as several biochemical parameters responsible for enhancement seed protein quality.S is a constituent of Met (21\%), the first amino acid incorporated during protein synthesis and it also linked to proper functioning of NR. ${ }^{130,131}$ the enzyme regulating the flow of $\mathrm{NO}_{3}-\mathrm{N}$ in to the amino acid and subsequently in to protein. ${ }^{13}$ Moreover, arginine response to $\mathrm{S}$ deficiency used as an indicator in field conditions. With $\mathrm{S}$ deficiency, amino acids accumulate and protein cannot be synthesized which may inhibit N-fixation. ${ }^{132} \mathrm{~S}$ increased nitrogenase activity because of higher ferredoxins and ATP concentration in bacteroid of root nodules of legumes. ${ }^{38}$ However, under condition of reduced S supply, arginine contributed 23 and $36 \%$ of total free amino acids at 0.125 and $0.075 \mathrm{mM} \mathrm{S}$ respectively. The potential of using biochemical indicator such as arginine response to S deficiency prior to changes in growth for the prediction of $\mathrm{S}$ deficiency in a large number of crops needs further research. If arginine responds early enough, its use as an S deficiency indicator will be greatly enhanced. ${ }^{133}$ Moreover, Wollaston ${ }^{134}$ suggested that proteins content in leaves can be rapidly degraded according to the need by other plant tissue. Kinetin may recover the decline of protein during senescence (Mancera et al., 1999). It is proposed that kinetin might have been implicated directly in the process of regulating protein transcription and translation. ${ }^{135} \mathrm{~S}$ application increased rate of potassium due to an increment in protein synthesis and maintenance of high chlorophyll content. ${ }^{136}$ Similarly, results of increased seed yield due to application of S were found by Srinivasarao et al., ${ }^{137}$ and Raina \& Tanawade. ${ }^{138}$ Besides this, application of S also improves the status of S-containing amino acids in the seed protein of chickpea because seeds have some capacity to increase their rate of $\mathrm{S}$ assimilation and $\mathrm{S}$ amino acids biosynthesis in response to an added demand. ${ }^{139}$ Furthermore, evaluation of amino acid profile under S-starvation conditions showed two to four fold enhancement in the contents of arginine, asparagines and OAS, whereas the contents of Cys and Met are reduced heavily. Exogenous supply of metabolites (arginine, asparagine, Cys, glutamine, OAS, and Met) also affected the uptake and assimilation of $\mathrm{NO}_{3}{ }^{2-}$, with a maximum for OAS. Therefore, this tight interconnection of S-nutrition with $\mathrm{NO}_{3}^{2-}$ assimilation and that OAS plays a major role in this regulation and must be helpful in developing a nutrientmanagement technology for optimization of crop productivity in future. ${ }^{140}$ Moreover, $\mathrm{S}$ deficiency resulted in lower $\mathrm{N}$ concentration of nodules. Furthermore, the decrease in $\mathrm{N}$ concentration under $\mathrm{S}$ deficiency implies a parallel decrease in $\mathrm{N}$ fixation, which may be indicative of an S limitation on protein synthesis. ${ }^{40,105}$

(d) Carbohydrate content: Carbohydrate content of chickpea seeds were observed to be invariably influenced with the application of growth substances and supplementation of S-fertilizer. $\mathrm{GA}_{3}$, kinetin and IAA are found to be highly effective PGR for carbohydrate metabolism in chickpea. Kaur et al., ${ }^{141}$ reported that amylase activity in cotyledons decreased by drought stress but increased by $\mathrm{GA}_{3}$ and kinetin after sowing while IAA reduced root amylase activity and neither $\mathrm{GA}_{3}$ or nor kinetin increased the amylase activity of roots. The higher level of reducing sugars in the shoot of $\mathrm{GA}_{3}$ and kinetin-treated stressed seedlings could be due to the high activity of sugar phosphatise syntheses (SPS) in shoot tissue. Moreover, the reducing the acid and alkaline invertase activity in shoots of stressed seedlings were enhanced by $\mathrm{GA}_{3}$ and kinetin. It may be assumed that photosynthetic translocation to root and nodules may also become a limiting factor in $\mathrm{N}$ fixation of S-starved leguminous plants. $\mathrm{N}$ fixation is a quite sensitive process to supply of photosynthetic assimilates. ${ }^{142,143}$ and the decline in nodule activity is associated with the development of the pods as a competing assimilate sink, since the decline in nodule activity coincided with the tip when pod growth rate first exceeded total CGR. Modification of soil with glucose, arabinose, sucrose and xylose has increased the rhizobium population significantly compared to unmodified soil ${ }^{109,144}$ The high demand of available carbohydrates for $\mathrm{N}$ fixation under optimum conditions is reflected in the amounts of glucose and sucrose in the nodules provided by the shoots. After the transport of carbohydrates in the nodules, they are metabolized to form organic acids to covert the energy demand of nitrogenase. ${ }^{105}$ Moreover, under S-deficient conditions, the amounts of glucose and fructose stayed on the same level, indicating that vegetative and reproductive growth of the plant has preference. Furthermore, the observations of Scherer et al., ${ }^{105}$ also observed that under S deficiency conditions, $\mathrm{S}$ and $\mathrm{N}$ concentration as well as the amounts of glucose 
and sucrose in shoots and nodules are significantly reduced. Increased accumulation of carbohydrates observed under S deficiency stress. ${ }^{146}$ Kinetin treatment significantly increased the sugar content of leaves at all stages more so at late pod fully stage. The effect of kinetin was greater in old leaves as compared to young leaves. The decrease in sugar content in kinetin treatment at flowering stage was greater in the old leaves as compared to the young leaves. ${ }^{10}$ Furthermore, ${ }^{147}$ reported the $\mathrm{Ck}$ balances the disproportionate distribution of assimilates in favour of the Ck-enriched shoot.

\section{Nitrate reductase activity and $\mathrm{NO}_{3}$ content}

Grain legumes can benefits cereal-production systems through enhanced soil $\mathrm{N}$-fertility associated with $\mathrm{N}$ fixation. The origin of nitrate is contentious. ${ }^{148,149}$ suggested that the nitrate most likely originates from mineralized rhizodeposits, legume roots, and nodules. $\mathrm{N}$ fixing legumes use less soil nitrate than an adjacent non- $\mathrm{N}$-fixing crop resulting in nitrate concentration or sparing. ${ }^{150}$ ATP-suphurylase, is the first enzyme of the $\mathrm{S}$ assimilation pathway and NR play a key regulatory role in the $\mathrm{NO}_{3}{ }^{2-}$ assimilation, is to be exploited that the activities of these enzymes are related to root, growth and yield. ${ }^{130,151-152}$ Haran et al., 2000). Chlorophyll content, ATP sulfurylase activity and protein content are also higher in transgenic plants than untranformed plants under S-insufficient conditions. ${ }^{154}$ In general, high concentration of Cys and GSH repress $\mathrm{S}$ assimilation activities, while $\mathrm{S}$ starvation results in increased activities of key enzymes in the assimilatory pathway. Administration of high concentration of Cys and GSH to plant roots leads to lowered steady state levels of mRNAs for the ATP sulfurylase and APS reductase. ${ }^{155,156}$ Plants root subjected to exogenous OAS exhibit an increase in accumulation of mRNA encoding the APS reductase. ${ }^{87,157}$ Moreover, deficiency of S in plants results in a reduction of NR activity and an accumulation of amino acids or soluble protein in chickpea seedlings of non-nodulating genotypes than nodulating genotypes and these results hint to a genetic variability of NR activity. ${ }^{158,159}$ Earlier, it is reported that NR is genetically controlled. ${ }^{160}$ However, the reduction of NR activity and mRNA level seem to be a relatively late process in plant adaptation to $\mathrm{S}$ limiting conditions. ${ }^{159}$ Moreover, N-metabolism is strongly affected by the S-status of the plant. S deficiency decreases the concentration of $\mathrm{N}$ in the shoot of legumes. ${ }^{105,161-163} \mathrm{NO}_{3}{ }^{2-}$ dramatically increased in $\mathrm{S}$ limited cells, probably as a consequence of the lowered activity of NR. For higher plants, it has been suggested that the down regulation of NR is mediated by products of N-accumulation like Gln, Asn and Arg. ${ }^{115,158}$ Furthermore, it has been reported that the NR is extremely susceptible to ammonium rather than to its metabolic products. ${ }^{115,164}$ The increased accumulation of $\mathrm{NO}_{3}{ }^{2-}$ may be correlated with a reduced synthesis of soluble protein due to the reduced availability of $\mathrm{SO}_{4}{ }^{2-}$.

\section{Carbonic anhydrase activity, leg haemoglobin content and nodule formation}

Since under S deficiency conditions, plant growth reduced the demand for $\mathrm{N}$ was lower too, and as a result in the decrease in nodule formation. ${ }^{165}$ may be viewed as an adjustment to a low demand for symbiotically fixed $\mathrm{N}$. The lower nodule yield was not only the results of smaller and fewer nodules per unit length of roots but also of a reduced root growth. ${ }^{33}$ Independent of the S supply, Scherer et al. ${ }^{105}$ observed the highest $\mathrm{S}$ concentrations in root nodules. According to Zhao et al., ${ }^{162}$ the high $\mathrm{S}$ concentrations in nodules as compared to roots and especially to shoots probably reflect the high $\mathrm{S}$ demand for the functioning of nodules. Nodules therefore provide a strong sink for S. On other hand, ferredoxins are acidic, low molecular weight, soluble $\mathrm{Fe}-\mathrm{S}$ proteins. In most instances, the $\mathrm{Fe}$ is bound via $\mathrm{SH}-$ groups of cysteine residues and also to inorganic $\mathrm{S}$ in Fe-S clusters. ${ }^{35}$ The main role of the Fe cluster is to facilitate electron transfer. Root nodule bacteria require access to adequate concentrations of $\mathrm{S}$ in their symbiotic relationship with legumes and $\mathrm{S}$ deprivation may bias $\mathrm{N}$ fixation by affecting nodule development and function. ${ }^{105}$ While, it is well established that nitrogenase activity is reduced under S deficiency conditions ${ }^{166}$ while Scherer et al., ${ }^{33}$ found no reports on the influence of $\mathrm{S}$ nutrition of legumes on the energy supply of nodules as well as their ferredoxin concentration. Jain et al., ${ }^{167}$ studied the effect of PGRs (IAA, $\mathrm{GA}_{3}$ and Kinetin) on haemoglobin biosynthesis in chickpea nodules and observed that almost all growth regulators showed a general promotory effect on its biosynthesis of haemoglobin. Kinetin being a growth-promoting hormone increased the nitrogenase activity of root nodules of chickpea ${ }^{168}$ and by increasing in the volume of pink bacteroid tissue; it also increased in leg haemoglobin contents and nodule bacteroid regions over control. Kinetin caused increase in leg haemoglobin content and nodule bacteroid region over the control. ${ }^{165}$ $\mathrm{N}$ fixation is drastically reduced in S-deficient plants as a consequence of a low nodule development, but also due to low nitrogenase and leg haemoglobin production. ${ }^{32,169}$

\section{Interaction effect on $\mathbf{N}$-fixation and nutrient use efficiency (NUE)}

The process of $\mathrm{S}$ acquisition and assimilation play an integral role in plant metabolism and response to $\mathrm{S}$ deficiency involves a large number of plant constituents. The results of Iacuzzo et al., (2011) showed that an increase in $\mathrm{S}$ availability enhanced nitrate $\left(\mathrm{NO}_{3}\right)$ uptake and assimilation, which, in turn, increased biomass production of leaves with lower $\mathrm{NO}_{3}$ content. In particular, high $\mathrm{S}$ availability exerted a positive effect (gene expression and functionality) on the uptake and metabolism of $\mathrm{N}$ and $\mathrm{Fe}$ acquisition mechanisms and their data show close interactions between $\mathrm{N}, \mathrm{S}$ and $\mathrm{Fe}$, highlighting that relevant improvements in yield and quality from soilless culture might also be obtained through appropriate adjustments of nutrient availability. In this respect, concerning the role of $\mathrm{S}$ in the acquisition mechanisms of $\mathrm{N}$ and Fe metabolism, its level of availability should be taken into high consideration for equilibrated plant growth. S deficiency in legume crops affect yield, quality and nutritional value of seeds. ${ }^{121,162,170}$ because Met is usually the most limiting essential amino acid in pulse seeds..$^{2,171}$ In chickpea, S application $(80 \mathrm{~kg} / \mathrm{ha})$ increase seed yield. Application of S containing fertilizers can result in soil acidification which may influence nutrient uptake. ${ }^{172}$ The yield response to optimum $\mathrm{S}$ application, however, differs among the various crop species, being lower in Medicago sativa and Pisum sativum as compared to Trifolium pratense and Vicia fava, suggesting that legumes differ in their S-requirement. ${ }^{165}$ Moreover, adverse effect of $\mathrm{S}$ deficiency on inorganic nutrition and biochemical processes might lead to the observed decrease in growth and finally may result in a decrease yield of chickpea. ${ }^{160,173}$ Since, the yield and quality of legume seeds are limited by the amount of S partitioned to the seeds. Moreover, the amino acid S-methyl Met (SMM), a Met derivative and a long-distance transport form of reduced S and whether SMM phloem loading and source-sink translocation are important for the metabolism and growth of pea plants. The changes in SMM phloem loading affected plant growth and seed number, leading to an overall increase in seed $\mathrm{S}, \mathrm{N}$, and protein content. The phloem loading and source-sink partitioning of SMM are important for plant $\mathrm{S}$ and $\mathrm{N}$ 
metabolism and transport as well as seed set. ${ }^{174}$ Symbiotic N fixation impaired under $\mathrm{S}$ deficiency conditions and calculated $\mathrm{N}$ fixation assuming that all $\mathrm{N}$ applied at planting was taken up completely under $\mathrm{S}$ deficiency conditions. ${ }^{33} \mathrm{~S}$ deficiency may affect $\mathrm{N}$ fixation of legumes by causing unfavourable conditions for $\mathrm{N}$ fixation in the host or because of the relatively high $\mathrm{S}$ content of nitrogenase, ${ }^{34}$ and of ferredoxins. ${ }^{35}$ The chief role of the Fe-S cluster of ferredoxin is to facilitate electron transfer and therefore ferredoxin plays a vital role in $\mathrm{N}$ fixation. ${ }^{175}$ A relationship between ferredoxin concentration and nitrogenase activity shown by Carter et al., ${ }^{176}$ Scherer et al., ${ }^{32}$ also investigated that the ferredoxin concentration of the bacteroid was significantly reduced under $\mathrm{S}$ deficiency conditions. Varin et al., ${ }^{177}$ examined whether the effect of $\mathrm{SO}_{4}{ }^{2-}$ addition on $\mathrm{N}$ fixation resulted from a stimulation of host plant growth, a specific effect of $\mathrm{S}$ on nodulation, or a specific effect of $\mathrm{S}$ on nodule metabolism. The application of $\mathrm{SO}_{4}^{2-}$ increased whole plant dry mass, root length, and nodule biomass, expressed on a root-length basis.

Nevertheless, $\mathrm{N}$ uptake proved less sensitive than $\mathrm{N}$ fixation to the effects of S-deficiency, and decreased as a consequence of the lower root length observed in S-deficient plants. This effect is likely to be due to down-regulation by a $\mathrm{N}$-feedback mechanism as under severe S-deficiency, the high concentration of whole plant $\mathrm{N}$ and the accumulation of $\mathrm{N}$-rich amino acids indicated that the assimilation of $\mathrm{N}$ exceeded the amount required for plant growth. As compared to subterranean clover supplied with $\mathrm{S}$ nodulation is markedly decreased in S-deficient clover. This is attributed to the decline in the requirement for $\mathrm{N}$ with reduced $\mathrm{S}$ supply. However, the observed increase in the number of nodules by S-fertilisation of legumes was not the result of increased nodulation per unit length of roots, but rather due to enhanced root growth. ${ }^{165,178,179}$ Moreover, $\mathrm{S}$ is a bio element; its superimposition increases the easy available carbon content of the soil because of a surge in the immobilization-mineralization activity. ${ }^{180}$ Thus the environment is created is found favourable for rhizobium activity. Hence the number of nodules and their activity increased following the application of S. Although the dry weight content of the nodules at higher level of applied S showed a tendency to increase, but it is not significant beyond $20 \mathrm{Kg} \mathrm{S} \mathrm{ha}^{-1} .{ }^{109} \mathrm{~A}$ response to applied $\mathrm{S}$ was observed to $20 \mathrm{Kg} \mathrm{S}^{-1}$ with respect to dry matter production but upto $40 \mathrm{Kg} \mathrm{S} a^{-1}$ with respect to seed yield. ${ }^{181}$ Moreover, the dry weight content of the nodules at higher levels of applied S showed a tendency to increase also. ${ }^{106,145}$ Moreover, pulse crop obtain N mainly from symbiotic $\mathrm{N}$-fixation which may be affected by $\mathrm{S}$ deprivation, ${ }^{105}$ and it is quite sensitive to supply of photosynthetic assimilates which indicate that decline in nodule activity under $\mathrm{S}$ deprivation is associated with development of pods. ${ }^{142}$ Nitrogenase and ferredoxin which play vital roles in $\mathrm{N}_{2}$-fixation are rich in $\mathrm{S}$ and contain $\mathrm{Fe}-\mathrm{S}$ clusters. Furthermore, with S-deficiency, amino acids and other N forms accumulate due to the impaired protein synthesis.

This could be due to the feedback repression of N-fixation. ${ }^{105,182,183}$ Mean while, Lang ${ }^{166}$ suggested that $\mathrm{S}$ affect leguminous species through its influence on $\mathrm{N}$-fixation by rhizobium species. If symbiotic $\mathrm{N}$-fixation has a greater requirement for a nutrient than the growth of host plants, a negative interaction between the addition of that nutrient and inorganic $\mathrm{N}$ on plant growth is expected. Gupta et al., ${ }^{90}$ investigate the effect of growth regulators on the nutrient uptake and protein yield of chickpea cv. JG-74. Moreover, they also reported that application of cytokinins showed higher contents of $\mathrm{N}, \mathrm{P}$ and $\mathrm{K}$ in seed compared to all the other treatments. The maximum N, P and $\mathrm{K}$ uptakes was observed in chickpea treated with $\mathrm{CK}$, a multifaceted plant hormone. ${ }^{94,184}$ studied the effect of fertility levels and PGRs on nutrients contents and uptake in chickpea cv. JG-322 and reported that the increasing levels of fertilizers up to P50S20 with FYM increased the contents and uptake of N, P, K and S almost significantly. Triacontanol (vipul) brought about the maximum uptake of NPK and S. Deo \& Khaldelwa ${ }^{185}$ studied the $\mathrm{S}$ interaction with $\mathrm{P}$ and indicated that grain and straw yield, content of $\mathrm{N}, \mathrm{P}$ and $\mathrm{S}$, uptake of $\mathrm{P}$ and $\mathrm{S}$ increased with increase in the rate of application of $\mathrm{P}$ and $\mathrm{S}$ individually as well as in various combinations. Applied $\mathrm{S}$ increased the number of nodule per plant and protein content in grain of chickpea. Also, Meena et al. ${ }^{103}$ reported that application of all levels of S and $\mathrm{Zn}$ progressively increased in grain yield, protein content, nutrient content and uptake by chickpea. $\mathrm{S}$ has become a major limiting factor for plant production in industrial as well as in remote industrial rural areas. Limitation of $\mathrm{S}$ can reduce legume $\mathrm{N}$ fixation by affecting nodule development and function. The effects of S deficiency on $\mathrm{N}$ fixation are likely to be caused by the shortage of ferredoxins and ATP. There was little concern for S deficiency even though the ability of the soil to retain and release it to crops is small. However, since the last two decades, the declining use of high-analysis low-S containing fertilizers and the reduction of $\mathrm{SO}_{2}$ emission from industrial sources are resulting in $\mathrm{S}$ deficiency of different crops.

\section{Interaction effect on quality parameters}

S-deficient plants generate a lower yield and have a reduced nutritional value. ${ }^{108} \mathrm{~S}$ is considered as important nutrient for its role in the production of amino acids Cys and Met as well as antioxidant GSH (glutathione). ${ }^{186}$ Reproductive growth and the proportion of the reproductive tissues in total dry matter are significantly increased by the application of S during pod development. Increase in dry weight with reduced $\mathrm{S}$ input can be described by the Piper-Steen-bjerg effect. ${ }^{187}$ Positive effect of $\mathrm{S}$ on seed yield and its quality is visible and significant when S content in soil is low. ${ }^{188-190}$ Analogically, S fertilisation does not influence the yield when $S$ content in soil is quite high. ${ }^{191} \mathrm{~S}$ supply only increase the S-concentration of the plants without enhancing the yield. Mandavia et al., ${ }^{28}$ reported a yield enhancement of methionine and carbohydrate content in chickpea seed cv. GG1 as well as quality improvement in chickpea seeds in terms of increased content of metabolite studied compared with higher seed yield point out to the beneficial effect of salicylic acid at vegetative as well as reproductive stages. $\mathrm{GA}_{3}$ led to comparatively more synthesis of nucleic acid while oxygenated peptone showed more increase in total carbohydrate and soluble protein contents in chickpea. ${ }^{106}$

\section{Interaction effect on nodule characteristics}

Under S limiting conditions, in pot experiments with different legumes, a lower $\mathrm{N}$ accumulation and a yield reduction was found. ${ }^{165} \mathrm{~S}$ also affect leguminous plant species growth through its effect upon $\mathrm{N}$ fixation by rhizobium microorganisms because of the relatively high $\mathrm{S}$ content of nitrogenase..$^{34,166,182,192,193} \mathrm{~S}$ is an essential macronutrient and at an optimum concentration accelerates the plant growth. ${ }^{194}$ Lawn and: ${ }^{195}$ indicate that decline in nodule activity coincided with the time when pod growth rate first exceeded total crop growth rate. Moreover, $\mathrm{S}$ has profound effect on creating assimilation area absorbing PAR (photo synthetically active radiation) and as a consequence on yield of crops ${ }^{133,196,197}$ Also, Scherer et al., ${ }^{105}$ assumed that reduced amount of available photosynthetic with suboptimal S supply could become limiting to energy production and as a carbon skeleton for ammonia assimilation and therefore cause a lower $\mathrm{N}$ fixation and the reduced 
yield formation. Furthermore, Fatima et al., ${ }^{100}$ reported that both the efficiency and the longevity of nodules seem to be favourably affected by kinetin application. Dayal \& Bharti ${ }^{168}$ \& Garg et al., ${ }^{198}$ also observed kinetin induced increase in nodule dry weight as well as in the nitrogenase activity. Research work of Bano ${ }^{199}$ Fatima $\&$ Bano $^{200}$ and Fatima et al., ${ }^{100}$ demonstrated the positive role of Cks in nodulation. The nitrogenase activity of nodules was high at flowering stage as compared to pod filling stage. ${ }^{201} \mathrm{Singh}^{169}$ observed that PGRs like IAA, NAA and 2, 4-D, GA and Kinetin used as foliar spray brought considerable variations in nodulation. Moreover, the ABA seed soaking as well as foliar spray treatments significantly decreased nodule weight, nitrogenase activity of nodules etc. Kinetin and ABA has profound enhancing effect on leaf and nodule senescence in chickpea cv. CM88. Kinetin at $10-8 \mathrm{M}$ was found more effective than kinetin at 10-6 $\mathrm{M}$ which responsible for delays the nodule senescence. ${ }^{10}$ Islam \& Ali $^{202}$ assess the effect of $S(0,15$ and $39 \mathrm{~kg} / \mathrm{ha})$ and $\mathrm{P}(0,40$ and $80 \mathrm{~kg} / \mathrm{ha})$ on nodulation, $\mathrm{N}$-fixation and nutrient uptake by chickpea and reported that application of $\mathrm{P}$ and $\mathrm{S}$ significantly increased all these parameters as well as yield. P and S uptake correlated positively with $\mathrm{N}$-fixation. ${ }^{203-215}$

\section{Conclusion and future guidelines}

Chickpea is a protein rich crop and so proper maintenance of soil fertility is necessary to harvest its full potential. The benefits that chickpea can derive from PGR and S application may be related to the bioavailability of substrate carbon as well as release of other nutrients. A survey of the foregoing research literature reveals that traditional cultivars of chickpea responded variably to the applied PGRs and S separately under various agro climatic conditions. Our review tells the pivotal role played by the PGRs along with $\mathrm{S}$ on the plant growth and development by affecting various growth parameters like: shoot length, leaf area, leaf area index, fresh weight, dry weight, physiological characters like chlorophyll content, photosynthesis, protein content and leg haemoglobin content; biochemical characteristics like nitrate reductase activity, nutrient accumulation, nutrient use efficiency in addition to yield and quality attributes including seed yield, harvest index and many other important aspects.

\section{Acknowledgements}

We are grateful to the Dean, Professor P.P. Singh, Faculty of Applied Sciences and Humanities, Bareilly, for providing research facilities. We are also grateful to Prof L.N. Sharma, for his critical comments and valuable suggestions with regard to the preparation of the manuscript.

\section{Conflict of interest}

There are no any conflicts of interest between the both authors in any respect of publication.

\section{References}

1. Shakya MS, MM Patel, VB Singh. Knowledge level of chickpea growers chickpea production technology. Indian Res $J$ of Ext Edu. 2008;8(2\&3):65-68.

2. Siddhuraju PK Vijayakumari, K Janardhanan. Chemical and protein quality of the little known legume, Velvert Bean (Mucura pruriens L.). Journal of Agriculture and Food Chemistry. 1996;44(9):2636-2641.

3. Saxena KB, RV Kumar, R Sultana. Quality nutrition through pigeonpea — a review. Health 2010;2(11):1335-1344.
4. Mazid M, Mohammad F. Environmental constraints responsible for reduction in productivity of chickpea: Revisit an old problem. International Journal of Environmental Engineering and Management. 2012;3(5):32-35.

5. Bhaguna RN, Shah D, Jha J. Effect of mild temperature stress on production dynamics and yield of chick pea (Cicer arietinum L.). Indian Journal of Plant Physiology. 2102;17:1-8.

6. Lekshmy S, J Vanita, K Sangeeta, et al. Effect of elevated carbon dioxide on kinetics of nitrate uptake in wheat roots. Indian Journal of Plant Physiology. 2009;14(1):16-22.

7. Phondke GP, Ramachandran K. The wealth of India, a dictionary of Indian raw materials and industrial products Raw materials. Publication and information Directorate, CSIR, New Delhi; 1992.

8. Singh AK, GP Singh, B Singh. Correlates of farmers knowledge of improved chickpea production technology. Indian Journal of Extension Technology. 2002;38:162-167.

9. Dutta D, Bandyopadhyay P. Performance of chickpea (Cicer arietinum L.) to application of phosphorous and biofertilizer in laterite soil. Archieves of Agronomy and Soil Science. 2009;55(2):147-155.

10. Ali S, Bano A. Leaf and nodule senescence in Chickpea (Cicerarietinum L.) and the role of plant growth regulators. Pakistan Journal of Botany. 2008;40(6):2481-2492.

11. Ahmad MKA, Afifi MH, Mohamed MF. Effect of bio fertilizer, chemical and organic fertilizers on growth, yield and quality of some leguminous crops. Egypt Journal of Agronomy. 2003;25:45-52.

12. Mohammadi K, Ghalavand A, Aghaalikhani M. Effect of different soil fertility strategies on absorption metabolism and molecular nitrogen fixation in chick pea. Iranian Journal of Pazhuhesh Sazandegi. 2011;91:78-79.

13. Mazid M, TA Khan, F Mohammad. Role of $\mathrm{NO}$ in $\mathrm{H}_{2} \mathrm{O}_{2}$ regulating responses against temperature and ultraviolet induced oxidative stress in plants. Acta Biologica Indica 2012a;1(1):1-16.

14. Abo Shetia AM, Soheir AM. Yield components response of chick pea (Cicer arietinum L.) to phosphorous fertilization and micro-nutrients. Arab University Journal of Agriculture Science. 2001;9:235-243.

15. Pathak S, Namdeo KN, Chakravati VK. Effect of bio fertilizers diammonium phosphate and zinc sulphate on growth and yield of chick pea (Cicer arietinum L.). Crop Research. 2003;26:42-46.

16. Rupela OP. A visual rating system for modulation of chickpea. International Chickpea Newsletter. 1990;22:20-25.

17. Ahlavat IPS. Diagnosis and alleviation of minimal nutrient constraints in chickpea. In: Chickpea in the nineties: Proceed; second intern workshop on chickpea improvement, 4-8 Dec 1989, ICRISAT; Patan cheru; India; 1990.

18. Samiullah NA Khan. Physiological investigation on interactive effect of $\mathrm{P}$ and $\mathrm{K}$ on growth and yield of chick pea. Indian J Plant Physiol. 2003;8(2):165-167.

19. Ali M, Mishra JP. Nutrient management in pulses and pulse-based cropping systems. Fertilizer News. 2000;45(4):57-69.

20. Duke JA. Handbook of legumes of world economic importance. Plenum Press, New York; 1981.

21. Serraji R, J Adu-Gyanji. Role of symbiotic $\mathrm{N}$ fixation in the improvement of legume productivity under stressed environments. West African Journal of Applied Ecology. 2004;6(1):95-109.

22. Khan TA, M Mazid, F Mohammad. Climatic change, sustainable agriculture and future needs: A perspective of parallel re-thinking. 
Journal of Industrial Research and Technology. 2012;1:1-5.

23. Jood S, S Bishnoi, A Thaina. Chemical analysis and physio-chemical properties of chick-pea and lentil cultivars. Nalrung. 1998;42(2):71-44.

24. Despande SS. Food legumes in human nutrition: a personal perspective. Reviews in food Science and Nutrition. 1992;32(4):333-363.

25. FAO/WHO. Energy and protein requirements. Nutrition Reports Series 724, Geneva; 1985.

26. Mazid M, Khan TA, Mohammad F. Effect of abiotic stress on synthesis of secondary plant products: A critical review. Agriculture Reviews. 2011;32(3):172-182.

27. Farzana W, Khalid IA. Protein quality of tropical food legumes. Journal of Science and Technology. 1999;23:13-19.

28. NRC. Recomended dietry allowance $9^{\text {th }}$ ed. Food and Nutrition Board NRC. National Academy of Sciences, Washington, DC; USA; 1981.

29. Khan NA, R Mir, M Khan, et al. Effect of gibberellic acid spray on nitrogen, yield efficiency of mustard grown with different nitrogen levels. Plant Growth Regulators. 2002;38(3):243-247.

30. Khan NA, Samiullah. Comparative effect of modes of gibberellic acid applications on Biomass distribution and productivity of rapseedmustard. Physiology and Molecular Biology of Plants. 2003;9:141-145.

31. Karim MF, QA Fattah. Growth analysis of chickpea CV. BAPI Chohla-6 as affected by foliar spray of growth regulators. Bangladesh Journal of Botany. 2007;36(2):105-110.

32. Ereifej KI, Al-karaki GN, Hammouri MK. Seed composition of improved chickpea and growth under semi-arid Mediterranean conditions. Journal of Food Properties. 2001;4(2):239-246.

33. Scherer HW, S Pacyna, K Spoth, et al. Low levels of ferredoxin, ATP and leghemoglobin contribute to limited $\mathrm{N}_{2}$ fixation of peas (Pisumsativum L.) and alfalfa (Medicagosativa L.) under S deficiency conditions. Biology Fertilizing Soils. 2008;44(7):909-916.

34. Mortensen LE, Thornley RNF. Structure and function of nitrogenase. Annual Reviews of Biochemistry. 1979;48:387-418.

35. Fukuyama K. Structure and function of plant type ferredoxin. Photosynth Res. 2004;81(3):291-301.

36. Nickell LG. Controlling Biological Behaviour of Plants with Synthetic Plant Growth Regulating Chemicals. Plant Growth Substances, ACS Symposium Series. 1979;111:263-279.

37. Yamazoe A, Hayashi K, Kepinski S. Characterization of terfestatin A, a new specific inhibitor for auxin signalling. Plant Physiol. 2005;139:779789.

38. Mazid M, Farah Naz. Repercussion of photosynthetic variables and related enzymes under influence of sodium dihydrogen orthophosphate and sodium sulphate with two modes of gibberellic acid application. Agricultural Science Digest. 2017a;37(1):51-55.

39. Selivankina SY, Karavaiko NN, Kuiper D. Cytokinin activity of zeatin allylic phosphate, a natural compound. Plant Growth Regul. 2001;33:157-164.

40. Mazid M, Fiza K. Application of Plant Derived Pesticides to Enhanced Castor Productivity and Yield Attributes. Med-Crave: Open Access Journal of Science. 2017b;2(1):2018:1-19.

41. Taiz L, Zeiger E. Plant Physiology. $5^{\text {th }}$ ed. Sinauer Associates, Inc., Sunderland, MA, USA; 2010.

42. Mazid M, Khalil K, Manoj K Srivastava, et al. Some improvement strategies for the sustainable chickpea development: Single or combined application of monosodium phosphate and sodium sulphate with or without gibberellic acid treatment by foliar or seed priming. Legume Research. 2017;40(4):660-668.

43. Tiwari KN, BR Gupta. Sulphur for sustainable high yield in Uttar Pradesh. Indian Journal of Fertilizers. 2006;1(11):37-52.

44. Salisbury R, H Ross. Plant Physiology. $4^{\text {th }}$ ed. Belmont, CA: Wadsworth, Inc; USA; 1992.

45. Davies PJ. The Plant hormones. Their nature, occurrence and functions. In: Davies PJ editor, Plant hormones, physiology, physiology biochemistry and molecular biology, $2^{\text {nd }}$ ed. Dordrecht, Kluwer Academic Publishers; 1995;1-12 p.

46. Khan NA, HR Ansari, Samiullah. Effect of gibberellic acid spray during ontogeny of mustard on growth, uptake and yield contribution. Journal of Agronomy and Crop Science. 1998;181(1):61-63.

47. Steudle E. Water uptake by roots: effects of water deficit. Journal of Experimental Botany. 2000;51(350):1531-1542.

48. Jayachandran M, NO Gopal, R Marimuthu. Performance of hybrid rice cultures under different levels of nitrogen in combination with growth regulators. Madras Agriculture Journal. 2000;89:462-465.

49. Zahir AZ, M Iqbal, M Arshad, et al. Effectiveness of IAA, GA3 and kinetin blended with recycled organic waste for improving growth and yield of wheat (Triticumaestivum L.). Pakistan Journal of Botany 2007;39(3):761-768.

50. Risheng T, Jinju Z, Guangnan W. Regulation of endogenous abscissic acid and indole acetic acid in rice plants by multiple effect of triazole. Jiangsu Journal of Agriculture Science. 1990;6:38-43.

51. Aswathanarayna SS, Mahadevappa M. Effect of gene locides in hybrid seed production of rice. Journal of Maharashtra Agriculture University. 1992;17:14-16.

52. Bui BB, Zaman FV, Singh VP. Studies to enhance hybrid seed production in rice. Omon Rice.1992;2:40-51.

53. Yuan LP, XO Fu. Technology of hybrid Rice production. FAO, Rome Italy; 1995; 84 p.

54. Pandey MP, Mani SC, Singh H. Hybrid Rice seed Production. A technology Manual. Power Printers, India; 1996.

55. Jayaraj T, Chandrasekharan. Foliar fertilization to changes seed yield and quality. In rice seed Research. 1997;25:50-52.

56. Subbaih G, BN Mittra. Effect of foliar spray of micro-nutrient on growth and yield of rice. Oryza 1997;26:148-151.

57. Yogesha HS, S Pandey, SP Sharma. GA3 to obtain synchrony in hybrid seed production. Seed Research. 2000;28(1):87-89.

58. Thangaraj M, M Laxiprabha, DD Devi. Physiological and biochemical effect of brassinolides on productivity of rice. Oryza. 2000;87:49-50.

59. Shi-Hua Y, C Ben-Yi, W Jian-Li, et al. Review and prospects on rice breeding and extension in China. Rice Science. 2006;13(1):1-8.

60. Elankavi S, Kuppuswamy G, Vaiyapuri V, et al. Effect of Phyto hormones on growth and yield of rice. Oryza. 2009;46(3):310-313.

61. Solaimalai A, C Sivakumar, S Anbumani, et al. Role of plant growth regulators in rice production: A review. Agric Rev. 2001;22(1):33-40.

62. Senthil A, M Djanaguiraman, R Chandrababu. Effect of root dipping of seedlings with plant growth regulators and chemicals on yield and yield components of rice (Oryzasativa L.) transplanted by broadcast method. Madras Agriculture Journal. 2003;90:383-384. 
63. Heitholt JJ, JJ Sloan, CT Mackown, et al. Soya bean growth on calcareous soil as affected by three iron sources. Journal of Plant Nutrition. 2003;26(4):935-948.

64. Bould C. Mineral nutrition of plants in soils. In: Plant physiology- $A$ treatise. Vol. III, FC Steward editor, Academic Press Incorporation, New York; 1963; 16-91 p.

65. Marschner H. Mineral nutrition of higher plants. $2^{\text {nd }}$ ed. Academic Press, London; 2002.

66. Matsubayashi YM, A Ogawa, Y Morita, et al. An LRR receptor kinase involved in perception of a peptide plabnthorone, phytosulfokine. Science 2002;296(5572):1470-1472.

67. Naqvi N Khan TA, Mazid M, et al. Phytoremediatory potential of Guava and Ashok tree at three different sites of Bareilly district-A case study: ARPN Journal of Agricultural and Biological sciences. 2014;9(3):101109.

68. Tabe LM, M Droux. Sulfur assimilation in developing lupin cotyledons could contribute significantly to the accumulation of organic sulphur reserves in the seed. Plant Physiology. 2001;126(1):176-187.

69. Droux M, Ruffet ML, Douce R, et al. Interactions between serine acetyltransferase and O-acetylserine (thiol) lyase in higher plants: structural and kinetic properties of the free and bound enzymes. Eur $J$ Biochem. 1998;225:235-245.

70. Khan TA, M Mazid. Nutritional significance of sulphur in pulse cropping system. Biology and Medicine. 2011;3(2):114-133.

71. Foyer $\mathrm{CH}, \mathrm{FL}$ Theodoulou, S Delrot. The functions of inter- and intracellular glutathione transport systems in plants. Trends Plant Sci. 2001;6(10):486-492.

72. Gutie'rez-Alcala G, C Gotor, AJ Meyer, et al. Glutathione biosynthesis in Arabidopsis trichome cells. Proc Natl Acad Sci U S A. 2000;97(20):11108-11113.

73. Khan TA, M Mazid, F Mohammad. Sulphur management: An agronomic and transgenic approach. Journal of Industrial Research \& Technology. 2011;1(2):147-161

74. McGrath SP, Zhao FJ, Withers PJA. Development of Sulphur Deficiency in Crops and Its Treatment. Proceedings No 379. The Fertiliser Society, Peterborough; England; 1996.

75. Hawkesford MJ. Plant responses to sulphur deficiency and the genetic manipulation of sulphate transporters to improve S-utilization efficiency. J Exp Bot. 2000;51(342):131-138.

76. Rotte C, Leustek T. Differential subcellular localization and expression of ATP sulfurylase and APS reductase during ontogenesis of Arabidopsis thaliana leaves indicates that cytosolic and plastid forms of ATP sulfurylase may have specialized functions. Plant Physiology. 2000;124(2):715-724.

77. Choi YE, Harada E, Wada M, et al. Detoxification of cadmium in tobacco plants: formation and active excretion of crystals containing cadmium and calcium through trichomes. Planta. 2001;213(1):45-50.

78. Hell R, R Jost, O Berkowitz, et al. Molecular and biochemical analysis of the enzymes of cysteine biosynthesis in the plant Arabidopsis thaliana. Amino Acids 2002;22(3):245-257.

79. Crawford NM, Kahn ML, Leustek T, et al. Nitrogen and sulfur. In: Buchanan BB, et al. editors. Biochemistry and Molecular Biology of Plants, Rockville, MD: American Society of Plant Biologists. 2000; 824-849 pp.

80. Leustek T. Sulfate metabolism. In: Somerville, et al. editors. The Arabidopsis Book. American Society of Plant Biologists, Rockville; 2002
81. Saito K. Sulfur assimilatory metabolism. The long and smelling road. Plant Physiology. 2004;136:2443-2450.

82. Grubb C, S Abel. Glucosinolate metabolism and its control. Trends Plant Sci. 2006;11(2):89-100.

83. Halkier BA, J Gershenzon. Biology and biochemistry of glucosinolates. Annu Rev Plant Biol. 2006;57:303-333.

84. Saito K. Regulation of sulfate transport and synthesis of sulphur containing amino acids. Curr Opin Plant Biol. 2000;3(3):188-195.

85. Hawkesford MJ. Transporter gene families in plants: the sulphate transporter gene family: redundancy or specialization? Physiologia Plantarum. 2003;117(2):155-163.

86. Fattah QA, DJ Wort. Effect of light and temperature on stimulation of vegetative and reproductive growth of bean plants by naphthenates. Agronomy Journal. 1970;62(5):576-577.

87. Islam MS, MF Karim, MJ Ullah. Effect of Knap and NAA on shoot dry matter, yield attributes and yield of lentil (Lens culinaries). Journal of Agriculture and Educational Technology. 2006;9(1-2):55-58.

88. Ullah MJ. Physilogical and biochemical responses of cowpea (Vigna unguiculata L.) following the application of growth regulators. Ph.D. thesis Department of Botany, Jahangirnagar University; Dhanka; Bangladesh; 2006.

89. Kumar N, SS Khangarot, RP Meena. Effect of sulphur and plant growth regulator on yield and quality parameters of chickpea (Cicerarietinum L.). Annals of Agricultural Research. 2003;24(2):434-436.

90. Gupta B, GK Shrivastava, V Annu. Response of plant growth regulators on nutrient uptake and protein yield of chickpea under vertisols of Chhattisgarh. Environment and Ecology. 2007;25(1):100-102.

91. Rao KLN, Reddy PJR, Mahalakshmi BK. Effect of PGR and micronutrient on flower absorption, pod setting and yield of chick pea. Annals of Plant Physiology. 2005;19:14-17.

92. Neelima A, Ranjana R, Kaur J. Alleviation of normal and late sown chickpea (Cicer arietinum L.) yield through foliar application of bio regulators. Environment and Ecology. 2006;24S(Special-1);147-176.

93. Tripathi DK, LC Bhusan, RS Baghal. Effect of some growth regulators on flower drop and yield of chick pea. Journal of Food legumes. 2007;20:117-119.

94. Chaurasia S, Chaurasia AK. Effect of fertility levels and growth regulators on nutrient contents and uptake of Chickpea (Cicer arietinum L.). Crop Research. 2008;76-80 p.

95. Tripathi DK, HC Singh, SKS Parihar. Effect of growth regulators on quality parameters in Chickpea (Cicerarietinum). Farm Science Journal. 2003;12(2):156-157.

96. Raut RS, Sabale RN. Studies on the yield maximization of chickpea cv.vijay through fertilizer and growth regulation under irrigated conditions. Journal of Maharashtra Agricultural Universities. 2003;28(3):311-312.

97. Mahukar DG, AM Dhopte, TH Rathod. Effect of anti be spirants and PGRs on yield of chick pea. Annnals of Plant Physiology. 2001;14:125128.

98. Namdeo TS, Kumar KN, Dwivedi MM. Effect of PGR on growth, yield and nutrient uptake of chick pea (Cicer arietinum L.). Crop Research (Hisar). 2001;21:301-307.

99. Kumaravelu G, VD Livingstone, MP Romanujam. Tricontanol-induced changes in the grass, photosynthetic plant, cell metabolites, floweing and yield of green gram. Biologia Planatarum. 2000;43:287-290. 
100. Fatima Z, A Bano, M Aslam. Effect of plant growth regulators and Rhizobiuminoculum on $N_{2}$ fixation and yield of chickpea. Proceeding of the $7^{\text {th }}$ international symposium of Nitrogen Fixation with Non-legume. Kluwer Academic Publisher, Great Britain; 1998. 103-106 pp.

101. Iqbal HF, MN Tahir, K I-ul Haq, et al. Response of chickpea (Cicer arietinum L.) growth towards the foliar application of gibberallic acid at different growth stages. Pakistan Journal of Biological Sciences. 2001;4(4):433-434.

102. Mazid M. Seed priming application of gibberellic acid on growth, biochemical, yield and protein status of Chickpea (Cicer arietinum L. cv. DCP 92-3). International Journal of Genetic Engineering and Biotechnology. 2014;5(1):17-22.

103. Meena SK, Sharma M, Meena HS. Effect of sulphur and zinc fertilization on yield, quality and nutrient content and uptake of chickpea under semi arid tropics. Annals of Botany. 2005;8(2):12-71.

104. Patil SV, Halikatti SI, Hiremath SM, et al. Effect of organic manures and rock phosphate on growth and yield of chickpea (Cicer arietinum L.) in vertisols. Karnataka Journal of Agriculture Science. 2011;24(5):636638 .

105. Scherer HW, SPacyna, NManthey, et al. Sulphur supply to peas (Pisumsativum L.) influences symbiotic N2 fixation. Plant Soil \& Environment. 2006;52(2):72-77.

106. Thakare U, N Patil, N Malpathak. Performance of Chickpea under the influence of gibberellic acid and oxygenated peptone during germination. Advances in bioscience and Biotechnology. 2011;2(1):40-45.

107. Shivakumar BG. Performance of Chickpea (Cicerarietinum L.) varities as influenced by sulphur with and without phosphorus. Indian Journal of Agronomy. 1999;46(2):273-276.

108. Sher S, SS Saini, BP Singh. Effect of irrigation, Sulphur and seed inoculation on growth, yield and sulphur uptake of chickpea (Cicer arietinum L.) under late-sown conditions. Journal of Agronomy 2004;49(1):57-59.

109. Ganeshamurthy AN, KS Reddy. Effect of Integrated Use of Farmyard Manure and Sulphur in a Soybean and Wheat Cropping System on Nodulation $\backslash$ Dry Matter Production and Chlorophyll Content of Soybean on Swell Shrink Soils in Central India. Journal of Agronomy and Crop science. 2000;185(2):91-97.

110. Stewart BA, LK Porter. Nitrogen-sulfur relationships in wheat (Triticumaestivum L.), Corn (Zea mays), and beans (Phaseolus vulgaris). Agronomy Journal 1969;61(2):267-271.

111. Lunde C, A Zygadlo, HT Simonsen, et al. Sulfur starvation in rice: the effect on photosynthesis, carbohydrate metabolism, and oxidative stress protective pathways. Physiol Plant. 2008;134(3):508-521.

112. Hajouj TR, S Gepstein. Cloning and characterization of receptor-like protein kinase gene associated with senescence. Plant Physiology. 2000;124:1305-1314

113. Chaloupkova K, Smart CC. The abscisic acid induction of a novel peroxidase is antagonized by cytokinins in Spirodelapolyrrhizal L. Journal of Plant Physiology. 1994;105:497-507.

114. Samet JS, TR Sinclair. Leaf senescence and abscisic acid in leaves of field-grown soybean. Plant Physiology. 1980;66(6):1164-1168.

115. Giordano M, V Pezzoni, R Hell. Strategies for the allocation of resources under sulphur limitation in the green alga Dunaliellasalina. Plant Physiol. 2000;124:857-886.

116. Li B, D Xing, L Zhang. Involvement of NADPH oxidase in sulfur dioxide-induced oxidative stress in plant cells. Photochem Photobiol Sci. 2007;6(6):628-634.
117. Dammgen U, Walker K, Grunhage L. The atmospheric sulphur cycle. In: E Schnug, editors. Sulphur in agro ecosystems, Kluwer Academic Publishers; Dorgrecht; Netherlands; 1998; 75-114 pp.

118. Davies JP, Grossman AR. Responses to deficiencies in macronutrients. In: M Goldschmidt-Clermont, et al, editors. The Molecular Biology of Chloroplast and Mitochondria in Chlamydomonas. Kluwer Academic Publishers, Amsterdam, Netherlands; 1998; 613-633 pp.

119. Jamal A, I Saeem, S Ahmad, et al. Effect of sulphur on nitrate reductase and ATP sulfurlyase Activities in groundnut (Arachis Hypogea L.). Journal of Plant biology. 2006;49(6):513-517.

120. Mazid M, Fiza K. Influence of Plant Based Pesticidal Application on Life Stages of Euproctis lunatus-A Hidden Factor for Reduced Yield of Castor. Global Journal of Entomology Research. 2017a:2(1):2017:1-28.

121. Sexton PJ, WD Bachelor, R Shibles. Sulphur availability, Rubisco content and photosynthetic rate of soybean. Crop Science. 1997;37(6):18011806.

122. Marschner H. Mineral nutrition of higher plants. $2^{\text {nd }}$ ed. Academic Press, London; 1995; 889 pp.

123. Grewal HS, SK Jaspinder, JS Kang. Effect of combined use of greenmanure and nitrogen on the productivity of maize (Zea mays). Indian Journal of Agronomy. 1992;37:635-638.

124. Caers M, Vendrig JC. Benzyladenine effects on the development of the photosynthetic apparatus in Zea mays: studies on photosynthetic activity, enzymes and chloroplast ultra structure. Physiologia Plantarum. 1986;66(4):685-691.

125. Hardy RWF, UD Havelk. Photosynthate as a major factor limiting $N_{2}$ fixation by field grown soybeans. In: Symbiotic nitrogen fixation in plants. Cambridge University Press, London; 1975. pp. 421-439.

126. Bethlenfalvay GJ, Phillips DA. Interaction between symbiotic nitrogen fixation, combined-N application and photosynthesis in Pisumsativum L. Physiologia Planatarum. 1978;42(1):119-123.

127. Yadav RM, Bharud RW. Response of Kabuli chickpea to the foliar application of growth substances. Mysore Journal of Agricultural Sciences. 2006;40:134-137.

128. Mandavia MK, C Karkar, C Mandavia, et al. Effect of salicyalic acid and brassinolide on yield and quality traits of chickpea seeds. India journal of Agricultural Biochemisrty. 2006;19(1):29-31.

129. Jyoti G, JS Sital, SK Batta. Effect of sulphur nutrition on biochemical parameters in developing chickpea (Cicerarietinum L.) seeds. Indian journal of Agricultural Biochemistry. 2007;20(2):59-62.

130. Ahmad A, AbrahamG, Abdin MZ. Physiological investigation of the impact of nitrogen and sulphur application on seed and oil yield of rapseed (Brassica campestris L.) and mustard (Brassica juncea L. Czern and Coss.) genotypes. Journal of Agronomy \& Crop Science. 1999;183(1):19-25.

131. Quddasi S, Khan F, Mazid M. Quality status of nutrients, vitamins and hormones under pathological threats in tomato: Basic scenario. Medicinal Chemistry and Analysis. 2014;4(1):12-21.

132. Varin S, B Leveel, SL Lavenant, et al. Does the white clover response to sulphur availability correspond to phenotypic or ontogenetic plasticity? Acta Oecologica. 2009;35(3):452-457.

133. Steven GT, PE Bilsboron, TJ Hocking, et al. Effect of sulphur deficiency on the growth of sugar beat (Beta vulgaris). Journal of Science Food and Agriculture. 2000;80(14):2057-2062.

134. Wollaston BV. The molecular biology of leaf senescence. Journal of Experimental Botany. 1997;48(2):181-199. 
135. Brinegar C. Cytokinin binding protein and receptors. In: Mok DWS, et al. editors. Cytokinins, chemistry, activity and function. CRC Press. Boca Raton; USA; 1964; 217-232 pp.

136. Ahmad A, Abdin MZ. Photosynthesis and its related physiological variables in the leaves of Brassica genotypes as influenced by sulphur fertilization. Physiologia Plantarum.2000;110(1):144-149.

137. Srinivasarao $\mathrm{CH}, \mathrm{AN}$ Ganeshamurthy, M Ali, et al. Sulphur fractions, distribution and their relationship with soil properties in different soil types of major pulse growing regions of India. Communication in Soil Science and Plant Analysis. 2004;35(19-20):2757-2769.

138. Raina AK, Tanawade SK. Delineation of sulphur deficient areas of Maharashtra and crop response to sulphur application. Indian Journal of Fertilizers. 2005;1(7):61-67.

139. Chiaiese P, Ohkama Ohtsu N, Molvig L, et al. Sulphur and nitrogen nutrition influence the response of chick pea seeds to an added, transgenic sink for organic sulphur. Journal of Experimental Botany. 2005;55(404):1889-1901.

140. Kaur S, AK Gupta, N Kaur, et al. Antioxidant enzymes and sucrose synthase contribute to cold stress tolerance in Chickpea. Journal of Agronomy and crop science. 2009;195(5):393-397.

141. Kaur S, AK Gupta, N Kaur. Seed priming increases crop yield possibly by modulating enzymes of sucrose metabolism in chick pea. Journal of Agronomy and Crop Science. 2005;191(2):81-97.

142. Wheeler CT. The causation of the diurnal changes in nitrogen fixation in the nodules of Alnusglutosina. New Phytology. 1971;70(3):487-495.

143. Scherer HW. Sulphur in crop production-invited paper. European Journal of Agronomy. 2001;14(2):81-111.

144. Veteri EL, JS Schmidi. Ecology of indigenous soil rhizobia, response of Brady rhizobium japonicum to readily available substrates. Appl Environ Microbiol. 1987;53(8):1872-1875.

145. Vance CP, SS Miller, BT Driscoll. Nodule carbon metabolism: Organic acids for $\mathrm{N}_{2}$ fixation. In: Elmeric E, editors. Biological Nitrogen Fixation for the $21^{\text {st }}$ Century. Kluwer Academy of Press Publication; Netherlands; 1998; 443-448 pp.

146. Bergman W. Nutritional Disorders of Plants. Development, Visual and Analytical Diagnosis. Gustav Fischer Verlag Jena. 1992;105-117.

147. Erwin HB. Regulation of shoot/root ratio by cytokinin from roots in Urticadioica: opinion. Plant and Soil. 1996;185(1):1-12.

148. Unkovich MJ, JP Pate, P Sanford. Nitrogen fixation by annual legumes in Australian Mediterranean agriculture. Australian Journal of Agricultural Research.1997;48(3):267-293.

149. Unkovich MJ, JS Pate. An appraisal of recent field measurements of symbiotic $\mathrm{N}_{2}$ fixation by annual legumes. Field Crops research 2000;65(2-3):211-228.

150. Chalk PM, Smith CJ, Hamilton SD. Characterization of the $\mathrm{N}$ benefit of a grain legume (Lupinusangustifolius L.) to a cereal (Hordeumvulgare L.) by an situ $\mathrm{N}^{15}$ isotope dilution technique. Biology and fertility of soils. 1993;15:39-44.

151. Reuveny Z, Dougall DK, Trinity PM. Regulatory coupling of nitrate and sulfate assimilation pathways in cultured tobacco cells. Proceedings of the National Academy of Science of USA. 1980;77(11):6670-6672.

152. Barney JPE, Bush LP. Interaction of nitrate and sulfate reduction in tobacco: I. Influence of availability of nitrate and sulphate. Journal of Plant Nutrition. 1985;8(6):507-515.

153. Clarkson DT, Luttge U. Mineral nutrition: Divalent cations, transport and compartmentalization. Progressive Botany. 1989;51: 93-112.
154. Abdin MZ, Akmal M, Ram M, et al. Constitutive expression of highaffinity sulfate transporter (HAST) gene in Indian mustard showed enhanced sulfur uptake and assimilation. Protoplasma. 2011;248(3):591600 .

155. Bolchi A, Petrucco S, Tenca PL, et al. Coordinate modulation of maize sulfatepermease and ATP sulfurylase mRNAs in response to variations in sulfur nutritional status: stereospecific down-regulation by l-cysteine. Plant Molecular Biology. 1999;39:527-537.

156. Lappartient AG, Vidmar JJ, Leustek $\mathrm{T}$, et al. Inter-organ signaling in plants regulation of ATP sulfurylase and sulfate transporter genes expression in roots mediated by phloem-translocated compound. Plant J. 1999;18(1):89-95.

157. Koprivova A, M Suter, RO Den-Camp, et al. Regulation of sulfate assimilation by nitrogen in Arabidopsis. Plant Physiology. 2000;122:737-746.

158. Migge A, Bork C, Hell R, et al. Negative regulation of nitrate reductase gene expression by glutamine or asparagines accumulating in leaves of sulfur-deprived tobacco. Planta. 2000;211(4):587-595.

159. Prosser IM, Purves JV, Saker LR, et al. Rapid disruption of nitrogen metabolism and nitrate transport in spinach plants deprived of sulphate. Journal of Experimental Botany. 2001;52:113-121.

160. Badruddin M, Karmoker JL. The effect of sulphur deficiency onion accumulation with special references to $15 \mathrm{~N}$ and $35 \mathrm{~S}$ transport in chickpea. PhD. Thesis, Dhaka University, Dhaka, Bangladesh, 2001

161. Andrew M. The partitioning of nitrate assimilation between root and shoot of higher plants. Plant cell Environment. 1977;9(7):511-519.

162. Zhao FJ, Hawkesford MJ, McGrath SP. Sulphur assimilation and effects on yield and quality of wheat. Journal of Cereals Science. 1999;30(1):117.

163. Jamal A, Y Moon, MZAbdin. Sulphur-a general overview and interaction with nitrogen. Australian Journal of Crop Science. 2010;4(7):523-529.

164. Franco AR, J Cardenas, E Fernandez. Ammonium (methylammonium) is the co-repressor of nitrate reductase in Chlamydomonasreinhardtii. FEBS Letters. 1984;176(2):453-456.

165. Scherer HW, A Lange. $\mathrm{N}_{2}$ fixation and growth of legumes as affected by sulphur fertilization. Biology and Fertility of Soils. 1996;23(4):449-453.

166. Lange A. Influence of sulphur supply on $N_{2}$ - fixation of legumes. Ph.D. Thesis; University Bonn; German; 1998.

167. Jain RK, AK Jain, VK Gera, et al. Effect of growth regulators on lag haemoglobin synthase in chickpea nodules. Legume Research. 2008;31:303-305.

168. Dayal J, Bharti S. Effects of Kinetin, cycocel and colchicine on nitrogenous activity and ATP production in Chickpea (Cicerarietinum L.). In: New trends in Plant Physiology proceeding, national symposium on growth and differentiation in plant. KK Dhir, et al. editors. India; 1991; 7019-375 pp.

169. Singh TB. Effects of growth regulators on nodulation and $\mathrm{N}_{2}$ fixation in Urdbean (Vignamungo L.). Comparative Physiology and Ecology. 1993;18(3):79-82.

170. Clarke EJ, Wiseman J. Developments in plant breeding for improved nutrition quality of soya beans II. Antinutritional factors. Journal of Agricultural Science. 2000;134:125-136.

171. Friedman M. Nutritional value of proteins from different sources: review. Journal of Agriculture \& Food Chemistry. 1996;44:6-29.

172. Havlin JL, JD Beaton, SL Tisdale, WL Nelson. Soil fertility and fertilizers, an Introduction to Nutrient Management. $7^{\text {th }}$ ed. Pearson education Incorporation, Singapore; 2007; 221-236. 
173. Mousavi SR. Zinc in crop production and interaction with phosphorous. Australian Journal Basic and Applied Sciences. 2011;5:1503-1509.

174. Tan Q, L Zhang, J Grant, et al. Increased Phloem transport of s-methylmethionine positively affects sulfur and nitrogen metabolism and seed development in pea plants. Plant Physiol. 2010;154(4):18861896.

175. Duke SH. HM Reisenauer. Roles and requirements of sulfur in plant nutrition. In: Tabatabai MA, editor. Sulfur in agriculture. Agronomy Monograph No. 27, American Society of Agronomy, Madison, Wisconsin, USA; 1986; 123-168 pp.

176. Carter KR, Rawlings J, Orme JohnsonWH, et al. Purification and characterization of ferredoxin from Rhizobium japonicum bacteroids. Journal of Biological Chemistry. 1980;255:4213-4223.

177. Varin S, JB Cliquet, E Personeni, et al. How does sulphur availability modify $\mathrm{N}$ acquisition of white clover (Trifoliumrepens L.)?. J Exp Bot. 2010;61(1):225-234

178. Vessey JK. Plant growth promoting rhizobacteria as biofertilizers. Plant Soil. 2003;255(2):571-586.

179. Schulze J, G Temple, SJ Temple, et al. Nitrogen fixation by white lupin under phosphorus deficiency. Ann Bot. 2006;98(4):731-740.

180. Saggar S, Bettany JR, Stewart JWB. Measurement of microbial sulfur in soil. Soil Biology and Biochemistry. 1981;13(6):493-498.

181. Ganeshamurthy AN. An evaluation of sulphur efficiency parameters in soybean and wheat cropping systems in relation to fertiliser $\mathrm{S}$ on a Typic Haplustert. Australian Journal of Agriculture Research. 1998;49:3-40.

182. Janssen KA, ML Vitosh. Effect of lime, sulphur, and molybdenum on $\mathrm{N}_{2}$ fixation and yield of dark red kidney beans. Agronomy Journal. 1974;66(6):736-740.

183. Paul MJ, Foyer CH. Sink regulation of photosynthesis. Journal of Experimental Botany. 2001;52:1383-1400

184. Mazid M, TA Khan, F Mohammad. Cytokinin: A classical multifaceted hormone in plant sytems. Journal of Stress Physiology and Biochemistry. 2011a;7:347-368.

185. Deo C, Khaldelwal RB. Effect of $\mathrm{P}$ and $\mathrm{S}$ nutrition on yield and quality of Chickpea (Cicer arietinum L.). Journal of the Society of soil science. 2009;57(3):352-356.

186. Jander G, V Joshi. Recent progress in deciphering the biosynthesis of aspartate derived amino acids in plants. Mol Plant. 2010;3(1):54-65.

187. Bates TE. Factors affecting critical nutrient concentrations in plants and their evaluation: a review. Soil Science. 1971;112(2):116-130.

188. Ahmad G, Jan A, Arif M. Influence of nitrogen and sulphur fertilisation on quality of canola (Brassica napus L.) under rainfed condition. Journal of Zhejiang University Science B. 2007;8(10):731-737.

189. Malhi S, Y Gan, J Raney. Yield, seed quality and sulphur uptake of Brassica oilseeds crops in response to crops to sulphur fertilization. Agronomy Journal. 2007;99(2):570-577.

190. Egesel CÖ, Gül MK, KahrIman F. Changes in yield and seed quality traits in rapeseed genotypes by sulphur fertilization. European Food Research and Technology. 2009;229(5):505-513.

191. Nowosielski O. Measurement of available sulphur and other sulphur forms using fungus Aspergillusniger. RoeznikiGleboznawcze $1961 ; 10: 165-174$

192. Mohammadi K, Sohrabi Y, Heidari G, Set al. Effective factors on biological nitrogen fixation. African Journal of Agricultural research. 2012;7(12):1782-1788.
193. Yoch DC. Electron-transport systems coupled to nitrogenase. In: RWF Hardy, editor. A Treatise on Dinitrogen Fixation. John Wiley and Sons. New York; 1979; 605-652 pp.

194. Thomas SG, PE Bilsborrow, TJ Hocking, et al. Effect of sulphur deficiency on the growth and metabolism of sugar beet (Beta vulgariscv Druid). Journal of Science Food and Agriculture 2000;80(14):20572062.

195. Lawn RJ, WA Brun. Symbiotic nitrogen fixation in soybeans. I. Effect of photosynthetic sourcesink manipulations. Crop Science. 1974;14(1):1116.

196. Lambers H, ML Cambridge, H Konings. Causes and consequences of variation in growth rate and productivity of higher plants. SPB Academic Publication, The Hague; 1990.

197. Blake Kalff MM, Harrison KR, Hawkesford MJ, et al. Distribution of Sulphur with in oilseed rape leaves in response to sulphur deficiency during vegetative growth. Plant physiology. 1998;118(4):1337-1344.

198. Garg N, IS Dua, SK Sharma. Nitrogen fixation ability and its dependence on the availability of cytokinin in soya bean and chickpea growing under saline conditions. Plant physiology and Biochemistry, New Delhi $1995 ; 22: 12-16$.

199. Bano A. Effect of kinetin on seedling growth and nodulation of salt stressed Vignaradiata. In: Prospects for bio saline research. Proc. US-Pak. Bio saline Research Workshop, Ahmad, et al editors. Botany Department, Karachi University, Pakistan, 1986;327-337.

200. Fatima Z, A Bano. Effects of seed treatment with growth hormones and Rhizobiumon the oil contents, nitrogen fixation and yield of soybean. Pakistan Journal of Botany. 1998;30(1):83-86.

201. Vessey KJ. Cultivars differences in assimilate partitioning and capacity to maintain $\mathrm{N}_{2}$ fixation rate in Pea during pod filling. Plant and Soil. 1992;139(2):185-194.

202. Islam M, S Ali. Effect of integrated application of Sulphur and Phosphorus on Nitrgen fixation and Nutrient uptake by Chickpea (CicerarietinumL.) Agrociencia. 2009;43(8):815-826.

203. Eriksen J, Thorup Kristensen K, Askegaard M. Plant availability of catch crop sulphur following spring incorporation. Journal of Plant Nutrition \& Soil Science 2004;167(5):609-615.

204. Fatima Z, S Bano, R Sial, et al. Response of chickpea to plant growth regulators on nitrogen fixation and yield. Pakistan Journal of Botany. 2008;40(5):2005-2013.

205. Iqbal A, IA Khalil, A Nadia, et al. Nutritional quality of important food legumes. Food Chemistry 2006;97(2): 331-335.

206. Khan NA, NA Loan, Samiullah. Response of mustard to applied nitrogen with or witout ethrel spray under non-irigated conditions. Journal of Agronomy and crop Science. 2000;184(1):63-66.

207. Krouma A. Physiological and nutritional responses of chick pea (Cicer arietinum L.) to salinity. Turk J Agric For. 2009;33:503-512.

208. Kutz A, A Muller, P Henning, et al. A role for nitrilase in the regulation of root morphology in sulphur-starving Arabidopsis thaliana. Plant Journal. 2002;30(1):95-106.

209. Marek LF, CR Stewart. Photosynthesis and photorespiration in presenescent, senescent and rejuvenated soybean cotyledons. Plant Physiol. 1992;98(2):694-699.

210. Mazid M, Khan TA, Mohammad F. Role of nitrate reductase in nitrogen fixation under photosynthetic regulation. World Journal of Pharmaceutical Researc. 2001;1(3):3-28. 
211. Mazid M, Farah Naz. Effect of Macronutrients and Gibberellic Acid on Photosynthetic Machinery, Nitrogen-Fixation, Cell Metabolites and Seed Yield of Chickpea (Cicer arietinum L.). Open Access Journal of Science. 2017;1(4):2017:2-11.

212. Rao KVM, Sresty TVS. Antioxidative parameters in the seedlings of pigeon pea (Cajanus cafenis L. Millspaugh) in response to $\mathrm{ZnO}$ and $\mathrm{Ni}$ stresses. Plant Science. 2000;157(1):113-128.

213. Sexton PJ, NC Paek, R Shibles. Soybean sulphur and nitrogen balance under varying levels of available sulphur. Crop Science. 1998;38(4):975982.
214. Tiwar DK, P Pandey, SP Giri, et al. Effect of GA3 and other plant growth regulators on hybrid rice seed production. Asian Journal of Plant Sciences 2011;10(2):133-139.

215. Yadav RM, RW Bharud. Effect of PGRs substances on yield of kabuli chickpea (Cicer arietinum L.). Journal of Maharashtra Agriculture University. 2009;34(1):28-29. 